\title{
Sedimentary Organic Matter Characterization on a Tropical Continental Shelf in Northeastern Brazil
}

\section{Roberto Lima Barcellos ${ }^{*}$, Maria Cristina da Silva Sales de Melo ${ }^{1,2}$, Alcides Nobrega Sial ${ }^{3}$, Valdir do Amaral Vaz Manso}

${ }^{1}$ Labogeo/GSGMar, Oceanography Department, Federal University of Pernambuco, Recife, Brazil

${ }^{2}$ LGGM, Geology Department, Federal University of Pernambuco, Recife, Brazil

${ }^{3}$ NEG-Labise, Geology Department, Federal University of Pernambuco, Recife, Brazil

Email: ^roberto.barcellos@ufpe.br

How to cite this paper: Barcellos, R.L., Melo, M.C.S.S., Sial, A.N. and Manso, V.A.V. (2020) Sedimentary Organic Matter Characterization on a Tropical Continental Shelf in Northeastern Brazil. International Journal of Geosciences, 11, 393-419. https://doi.org/10.4236/ijg.2020.116021

Received: May 19, 2020

Accepted: June 26, 2020

Published: June 29, 2020

Copyright $\odot 2020$ by author(s) and Scientific Research Publishing Inc. This work is licensed under the Creative Commons Attribution International License (CC BY 4.0).

http://creativecommons.org/licenses/by/4.0/

\begin{abstract}
In continental shelf areas works where the focus is Geochemistry are widely relevant, due to the vast complexity and uses of these relief features (social, environmental and economic). On the Brazilian Northeast tropical shelves, with emphasis on the Pernambuco Continental Shelf (PCS), the published studies are limited and have aimed at portions closer to the coastline. The objective of the present work is the description of the characteristics and origin of sedimentary organic matter (SOM) in the inner and middle Pernambuco shelf, defining and classifying the local geochemical sedimentary facies. The sampling stations (136) were collected in the study area, and the grain-size, contents of total organic matter (TOM), calcium carbonate $\left(\mathrm{CaCO}_{3}\right)$ were analyzed. The samples were processed in an elemental analyzer coupled with a mass spectrometer after the elimination of calcium carbonate. The obtained data were the grain-size, $\mathrm{TOM}, \mathrm{CaCO}_{3}$, elemental $(\mathrm{C}, \mathrm{N})$ and the stable isotopic ratios of $\delta^{13} \mathrm{C}$ e $\delta^{15} \mathrm{~N}$ of SOM. Based on the measured values of carbon and nitrogen, the $\mathrm{C} / \mathrm{N}$ ratio, associated to $\delta^{13} \mathrm{C}$ e $\delta^{15} \mathrm{~N}$, is observed that in the PCS predominates an organic matter of marine origin along its entire length: $\mathrm{C}<1 \%, \mathrm{~N}<1 \%, \mathrm{C} / \mathrm{N}<5, \delta^{13} \mathrm{C}>-21$ PDB e $\delta^{15} \mathrm{~N}>8_{\text {Ar }}$. The PCS presents patches of continental origin SOM, associated to the coastal zones adjacent to estuarine systems mouths and covering the paleochannels, which may indicate that this material was carried from the coastal rivers to the offshore areas, possibly by the paleo-valleys that also act as traps of fine sediments and SOM. The statistical analysis indicates the existence of 6 different sedimentary facies and a prevalence of one of them, characterized by poorly-sorted bioclastic sandy-gravel, with low to medium organic contents of marine origin. This
\end{abstract}


indicates that the coastal sedimentary material contributions are low and the local cover is autochthonous of biogenic origin, and deposited according to the surficial topography, morphosedimentary processes and meteoceanographycal conditionings of the study area, typical of moderate hydrodynamic energy environments.

\section{Keywords}

Biogenic Sediments, Total Nitrogen, $\delta^{13} \mathrm{C}$ Stable Isotopic Ratio, Geochemical Facies, Pernambuco

\section{Introduction}

The continental shelves could be defined as relief features of the continental margin, whose main characteristic is being the continuity of the continental domain below the seawater level [1] [2]. This physiographical province represents $8.91 \%$ of all oceanic basins, although concentrates around $90 \%$ of economically important marine resources, as fossil fuels and minerals. Besides this develops the major part of the human activities as transport, artisanal and industrial fishing, tourism, research, and others [3] [4] [5]. In this way is an environment of extreme social, economic and environmental importance, which there is demand of sustainable exploitation in its activities in order to not address any environmental degradation [6]. The continental shelves are dynamic environments, whose extension vary along the geological time and eustatic sea level fluctuations, could even disappear if the regression overcomes the shelf break [5].

The transport and deposition processes associated to those eustatic variations result in the allochthonous and autochthonous sedimentary materials produced on the shelf, being deposited in its surface features or transported according to the local hydrodynamics. In this way the sediments, terrestrial or marine, are products of its predominant nature, where the organic and inorganic particles accumulate bringing with them the historical registers about the environment, by means of textural classification, grain maturity and composition. This marine dynamics is responsible by the complex sedimentary mosaic existing in the shelf, ordering ancient relict and recent materials composition [7] [8] [9].

Among such sedimentary complexity, there's the sedimentary organic matter (SOM) as one of the marine sediments components, which bring information about the biogeochemical interactions between atmosphere, biosphere and geosphere [10]. Besides the hydrodynamics circulation already mentioned, the SOM is influenced mainly by the marine and continental inputs, where its study allows inferences about its sources and origin [11] [12]. The organic contents are correlated to a serial of factors as sedimentary dynamics, water column productivity, microbial consumption taxes, all associated to hydrological and oceanographic conditions [11] [13]. The characterization of organic matter present in 
the sediments is of extreme importance in environmental studies, since the interpretations of its occurrence represents a great contribution about the cycle-origin, nature and destiny-of this matter in the marine environment, besides the comprehension over the carbon global cycle [14].

The carbon, due to its molecular properties, is an essential element for life, being present in all organisms [15]. The nitrogen, among the essential elements of life (C, P, O, S, N and silicates), presents major abundance in the atmosphere and biosphere [16]. It is also present in the fundamental activities of life, being one of the main nutrients for the marine and terrestrial primary production [17]. The carbon $(\mathrm{C})$ and nitrogen $(\mathrm{N})$ are chemical elements that has more than one isotopic form, and the isotopic natural composition of these elements can be measured, with high accuracy, employing a mass spectrometer [18] [19].

The C/N elemental ratio, according to Saito et al., (1989), presents values possible to correlate with local geological conditions, acting as a geochemical tool for environmental characterization. Reference [20], classify the values $<4$ as polychaetes origin organic material. References [11] and [21] classify the $\mathrm{C} / \mathrm{N}$ ratio according to the intervals: 4 to 7 phytoplankton; 8 to $12 \mathrm{mix}$ between terrestrial and planktonic material; and $>20$ as terrigenous input from superior plants $\left(\mathrm{C}_{3}\right)$.

The stable isotopes use, as natural tracers of organic matter origin is reasoned in the possible differences among its signatures of several sources, between each distinct isotope indicative of material sources/origin. Besides this, these signatures are preserved stable during the mineralization, transport and sediments accumulation [22]. The use of two variables as proxies for SOM characterization leads to a more efficient results, since the indicative values of $\delta^{13} \mathrm{C}$ may coincide even from different sources, thus making necessary the use of another variable, such as $\delta^{15} \mathrm{~N}$ [23]. In the case of $\delta^{15} \mathrm{~N}$ [24] [25] affirms that such contents cannot be configured as the only parameter, due to the signatures overlapping that a sediment may have according to the interactions of the surroundings. The evaluation of SOM typical isotopic ratios values from shelf environments [11] [21] [26] [27] [28] [29], together with the indicative contents observed in the coastal zone of the study area [30] [31] [32] [33] [34], is observed that the values of $\delta^{13} \mathrm{C}>$ $-21.0 \mathrm{PDB} \%$ are classified as more enriched in marine material, while the values of $\delta^{13} \mathrm{C}<-24.0 \mathrm{PDB} \%$ are typical of terrestrial origin.

Researches that deal with marine sedimentology and elemental and isotopic geochemistry are still incipient in the area, and there are no published works that represent the entire extension of Pernambuco Continental Shelf (PCS). There are related works, but limited to small sectors of the shelf, generally along the coast, such as those of [35] [36] [37]. In this way, the present work brings unprecedented data on the distribution, geochemical facies composition, and Sedimentary Organic Matter (SOM) classification, and the origin of inner and middle shelf of Pernambuco State (NE, Brazil), up to the $40 \mathrm{~m}$ deep isobath. It aims to classify faciologically the sediments of PCS, as well as to verify the extent of the modern coastal contributions based on the characteristics of SOM. 


\section{Study Area}

The Pernambuco Continental Shelf (PCS) is located at $07^{\circ} 32^{\prime}$ to $08^{\circ} 55^{\prime} \mathrm{S}$ parallels and $34^{\circ} 49^{\prime}$ and $35^{\circ} 09^{\prime} \mathrm{W}$ meridians. The PCS presents $155 \mathrm{~km}$ of length, reaching up to $35 \mathrm{~km}$ wide, with a shallow and flattened relief, whose shelf-break rests at an average depth of $65 \mathrm{~m}$ [38] [39] [40] [41]. According to [3] subdivision, the present work covers up to the middle shelf, which reaches the $40 \mathrm{~m}$ isobath (Figure 1).

In general lines, the shelf is composed by Paraíba and Pernambuco marginal sedimentary basins, with dated sediments from Neogen era is also limited by three structural highs and lineaments named from the north to south by: Mamanguape High, Pernambuco Lineament (Recife harbor) and Maragogi High, respectively. The region has "As" climate type according to Köppen Classification (warm and humid), with two marked seasons, rainy from April to September and dry from October to March, $27^{\circ} \mathrm{C}$ of average temperature and 2050 $\mathrm{mm} \cdot \mathrm{yr}^{-1}$ of rainfall [40]-[46].

The coastal region is bordered by the rivers and derived estuaries of Goiana and Una, together with Capibaribe, Ipojuca, Jaboatão-Pirapama and Sirinhaém, maintain regular water supply, added by the urban outfalls present in these river basins close to the coast [30] [31] [36] [40] [41] [47]. The sea water average temperature is $27.8^{\circ} \mathrm{C}$ and the salinity is $33 \mathrm{psu}$, oscillating through the contributions of the mentioned river systems [40] [47] [48]. According to [41], the region presents coastal waters (CW), due to the interactions with terrestrial inputs, although prevailing presence of oceanic warm and salty waters, in this case, the Tropical Water (TW) [47].
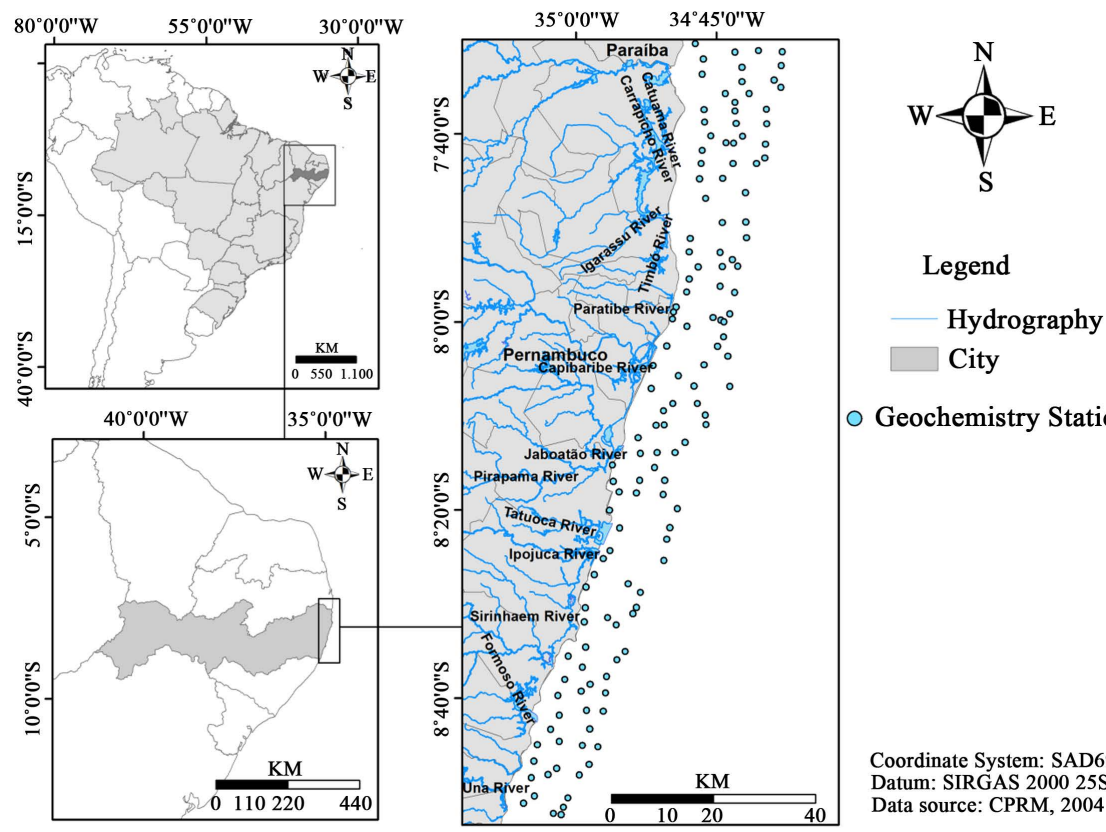

Geochemistry Stations

Figure 1. Study area and the sampling stations locations in Pernambuco Continental Shelf (PCS). 
Reference [3] classified the PCS based on topography and sediment cover in 3 compartments. First is the inner shelf that extends to the $20 \mathrm{~m}$ deep isobath reaching up to $6 \mathrm{~km}$ wide and presenting, in general, sandy siliciclastic/biosiliciclastic sediments and smooth relief. However, with irregularities due to the presence of cross-shelf paleo-valleys and beachrocks that serve as substrates for the development of corals and, mainly, calcareous algae. The middle shelf reaches $40 \mathrm{~m}$ depth with an average width of $21 \mathrm{~km}$, presenting a gravelly bioclastic character and a much more irregular relief. With the presence of representative waterways and paleovalleys, formed by the shelf exposition and dissection in previous times. The outer shelf, from 40 to $65 \mathrm{~m}$ depth, is about $7 \mathrm{~km}$ wide and is characterized by erosive features represented by ravines, valleys and crests arranged perpendicular to the coast. It evolved from a subaerial exposed carbonate shelf, when the subsequent sedimentation was not enough to cover it. The outer shelf presents a multiple step break, corresponding to shelf edge terraces, formed by wave abrasion, with associated shelf break $(-65 \mathrm{~m})$ and slope canyons.

According to [37] one of the main morphological features of the study area is the presence of lines of beachrocks parallel to the coastline, more prominent in the northern PCS, associated with the Eustatic variations of the Quaternary. Where it can be observed the presence of such formations in different depths $(-5,-16,-22,-25,-32$ and $-45 \mathrm{~m})$ [5], it being able to represent old beaches or waves abrasion terraces associated with periods of sea level stabilization. These features currently act as sequesters of terrigenous material, substrates for algae and protect the coast from waves. The cross-shelf paleo-valleys are also a common feature and have geographical correspondence with modern fluvial-estuarine basins and mouths [5].

\section{Methods and Materials}

\subsection{Grain Size Analysis}

Along the study area 136 samples were selected of seabed sediments, collected using a Van Veen grab sampler, sorted by the governmental project “GRANMAR BraziP”, subproject: “Mineral potential evaluation of marine granules in Brazilian coastal zone-PE/CE' of Mineral Resources Research Company of Brazil Geological Survey [49] (Figure 1). The surficial sediments were sampled in oceanographic cruises during the 2004 year, covering $2500 \mathrm{~km}^{2}$ of PCS. The GRANMAR Brazil project provided data for the grain-size analysis parameters and bathymetric data of PCS based on 136 points collected in 107 cross-shelf profiles. The profiles were spaced in 1 to 1 nautical mile until 30/40 $m$ depth isobaths, mapping the whole inner shelf and great part of the middle shelf, when it was possible. The gaps between the sampling stations are due to the presence of hard seabed and consequently, the absence of sedimentary cover.

The samples were kept frozen, and later freeze-dried for 48 hours. Grain size 
was analyzed by a sieving and pipetting method [50], the calcium carbonate $\left(\mathrm{CaCO}_{3}\right)$ and Total Organic Matter (TOM) contents were determined by the weight difference prior to and after acidification, with $1 \mathrm{~N} \mathrm{HCl}$ and $1 \mathrm{~N} \mathrm{H}_{2} \mathrm{O}_{2}$, respectively [51]. The grain size parameters were employed according to [52] faciological classification diagram and [53] statistical treatment. The textural classification used here was that of [54] [55], based in [56] replacing the term lithoclastic for siliciclastic due to the origin of the particles from rock fragments and silicatic local minerals (mudstones, sandstones and conglomerates), therefore more suitable for the sedimentary cover of the Brazilian northeastern shelf.

\subsection{The Elemental $(\mathrm{C}, \mathrm{N})$ and Stable Isotopic Ratios $\left(\delta^{13} \mathrm{C}, \delta^{15} \mathrm{~N}\right)$ Analyses}

As described in [57], was also performed in this procedure the calcium carbonate elimination with $10 \% \mathrm{HCl}$ solution [51]. Subsequently the samples were homogenized and macerated. Approximately $500 \mathrm{mg}$ of each sample was weighted in tin capsules on a Metler microanalytical balance, and then closed for packaging using tweezers. The capsules were allocated in the auto sampler for the elemental and isotopic $\mathrm{C}$ and $\mathrm{N}$ analyses. The analytical processes occurred by the sample automatic combustion (poorly structured) in an elemental EA (COSTECH), coupled with a mass spectrometer IRMS (Thermo Finnigan Delta $V$ Advantage). The process consisted in the encapsulated samples combustion in chromium oxide $(\mathrm{CrO})$ columns at $1020^{\circ} \mathrm{C}$. Then the material was carried to another column with ionized copper $\left(\mathrm{Cu}^{2+}\right)$ at $650^{\circ} \mathrm{C}$ for $\mathrm{N}_{2}$ and $\mathrm{CO}_{2}$ release, which were separated by ion exchange chromatography. The gaseous material was analyzed by mass spectrometer, which the $\mathrm{N}_{2}$ and $\mathrm{CO}_{2}$ were previously calibrated with international standards.

The $\mathrm{C}$ and $\mathrm{N}$ data, expressed in percent (\%), were obtained together with the values of carbon $\left(\delta^{13} \mathrm{C}\right)$ and nitrogen $\left(\delta^{15} \mathrm{~N}\right)$ isotopic ratios values. The samples were burned by oxidation, and the produced gases separated by gas chromatography, purified and carried by a continuous flow of helium. The isotopic ratio values of carbon $\left(\delta^{13} \mathrm{C}\right)$ and nitrogen $\left(\delta^{15} \mathrm{~N}\right)$ (in parts per thousand) are referred to PDB (Pee Dee Belemnite) and Air (atmospheric air), respectively. The C/N ratios values were obtained, in turn, by the simple division between the contents of each analyzed sample.

\subsection{Statistical Analyses}

For a better elemental and isotopic data discussion, added with the provided sedimentary composition characteristics, were employed for the statistical analyses of correlation and PCA. The non-parametric correlation coefficient of Spearman (rs) was used in order to compare how the spatial variability occurs and determine the independent relations between the parameters [58]. The correlation data are presented in Table 1.

The Principal Components Analyses (PCA) was performed to obtain the geochemical facies, since it correlates all parameters together. Primer 6 was the 
Table 1. Spearman $(r s)$ correlation coefficient.

\begin{tabular}{|c|c|c|c|c|c|c|c|c|c|c|}
\hline & Depth & $\begin{array}{c}\text { Gravel } \\
(\%)\end{array}$ & $\begin{array}{c}\text { Sand } \\
(\%)\end{array}$ & $\begin{array}{c}\text { Mud } \\
(\%)\end{array}$ & $\begin{array}{c}\text { TOM } \\
(\%)\end{array}$ & $\mathrm{CaCO}_{3}$ & $\%$ TOC & $\% \mathrm{TN}$ & $\begin{array}{c}\delta^{13} \mathrm{C} \\
\text { PDB\%o }\end{array}$ & $\begin{array}{r}\delta^{15} \mathrm{~N} \\
\text { Air\%o }\end{array}$ \\
\hline Depth & 1.00 & & & & & & & & & \\
\hline Gravel (\%) & -0.17 & 1.00 & & & & & & & & \\
\hline Sand (\%) & 0.10 & -0.67 & 1.00 & & & & & & & \\
\hline Mud (\%) & 0.07 & -0.33 & -0.48 & 1.00 & & & & & & \\
\hline TOM (\%) & 0.04 & 0.23 & -0.45 & 0.31 & 1.00 & & & & & \\
\hline $\mathrm{CaCO}_{3}$ & -0.40 & 0.43 & -0.28 & -0.16 & 0.16 & 1.00 & & & & \\
\hline$\%$ TOC & -0.03 & 0.06 & -0.05 & 0.00 & 0.06 & 0.18 & 1.00 & & & \\
\hline$\% \mathrm{TN}$ & -0.18 & -0.01 & 0.04 & -0.03 & 0.06 & 0.06 & 0.72 & 1.00 & & \\
\hline$\delta^{13} \mathrm{C}$ PDB $\%$ & -0.03 & -0.09 & 0.03 & 0.05 & -0.01 & -0.07 & 0.07 & 0.30 & 1.00 & \\
\hline$\delta^{15} \mathrm{~N}$ Air\%o & 0.06 & 0.27 & -0.12 & -0.15 & 0.25 & 0.05 & 0.22 & 0.28 & 0.26 & 1.00 \\
\hline
\end{tabular}

software used and the data was normalized by the function $\left[\log ^{10}(x+1)\right]$, for a better data elucidation. In this analysis, the parameters $\mathrm{N} \%$ e o $\delta^{15} \mathrm{~N}$ Air\%o were not used, since there were few detections in the material, which would result in misinterpretations, due to the absence of nitrogen [59]. Although for facies discussion the data are treated and worked together.

\section{Results and Discussion}

\subsection{Surface Sediments Distribution and Composition}

The inner and middle continental shelf region of Pernambuco (PCS) can be characterized as a mixed platform, composed by siliciclastic, carbonate-siliciclastic and carbonate sediment cover $\left(\mathrm{CaCO}_{3}>50 \%\right)$, and hosts several prominent features such as: banks, beach rocks, coral reefs, paleo-valleys, incised valleys and paleo coastlines. The PCS presents a predominance of sandy-gravelly (between $40 \%$ and $60 \%$ of samples) bioclastic sediments, poorly sorted with low organic content (predominant TOM $<2 \%$ ) over the whole studied area. This sedimentology pattern is relatively similar of those observed for Rio Grande do Norte continental shelf [54] [55].

According to the [52] textural diagram classification (Figure 2) is possible to observe five sedimentary facies: sand, gravelly-sand, sandy-gravel, mud-sand and mud, with the predominance of gravelly-sand facies in the whole of PCS. The mud facies are present along the coastline, mainly adjacent to the mouths of the following estuarine systems: Goiana, Paratibe, Jaboatão-Pirapama, Ipojuca-Suape and Una, also occurring in a great patch between the Maracaípe e Sirinhaém Rivers, already reported by [35]. While gravelly facies are present both on the inner shelf near to the rivers Goiana, Igarassu (Itamaracá Island), Capibaribe, Pirapama and Ipojuca; and in the middle shelf along the Goiana, Capibaribe, Ipojuca and Formoso rivers areas. 

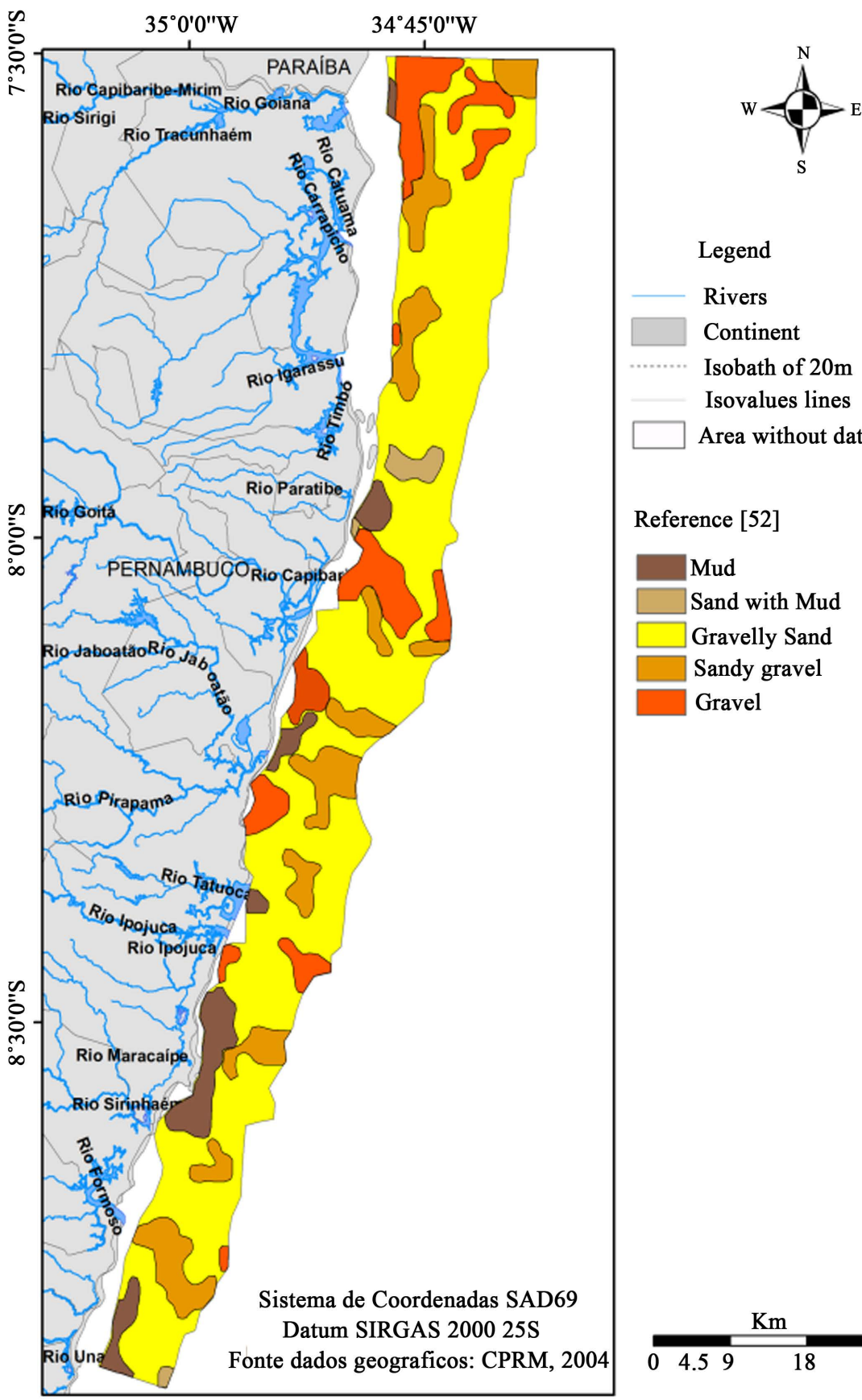

\section{Legend \\ Rivers \\ Continent \\ Isobath of $20 \mathrm{~m}$ \\ Isovalues lines \\ Area without data}

Reference [52]
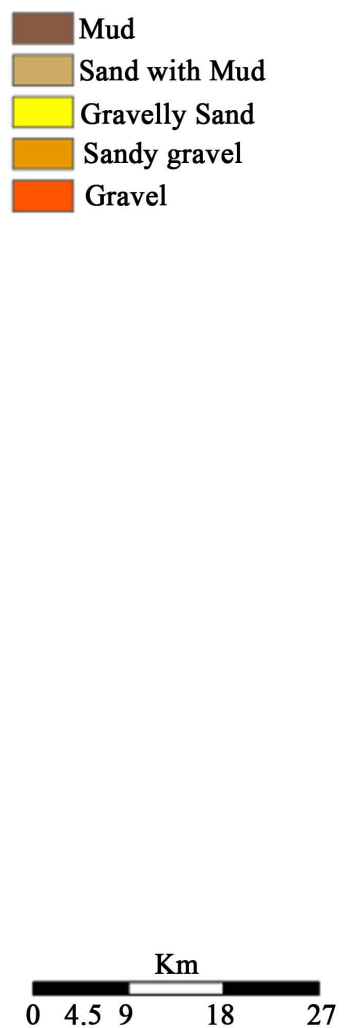

Figure 2. Reference [52] textural classification.

The TOM ranged from $0.20 \%$ to $9.30 \%$, with an average of $2.72 \%$ and prevailing values between $1.0 \%$ and $2.0 \%$, being in general low and typical of exposed continental shelves [60] [61]. The map of TOM (Figure 3) presents a spatial distribution pattern where the higher concentrations $(>3.0 \%)$ occur in the central portion of PCS towards the north, and in the south sector from Maracaípe river until the southern limit of PCS. Patches with contents above $4.0 \%$ are present adjacent to the mouths of Capibaribe and Paratibe estuarine systems, as well as in the inner shelf of Goiana river. 

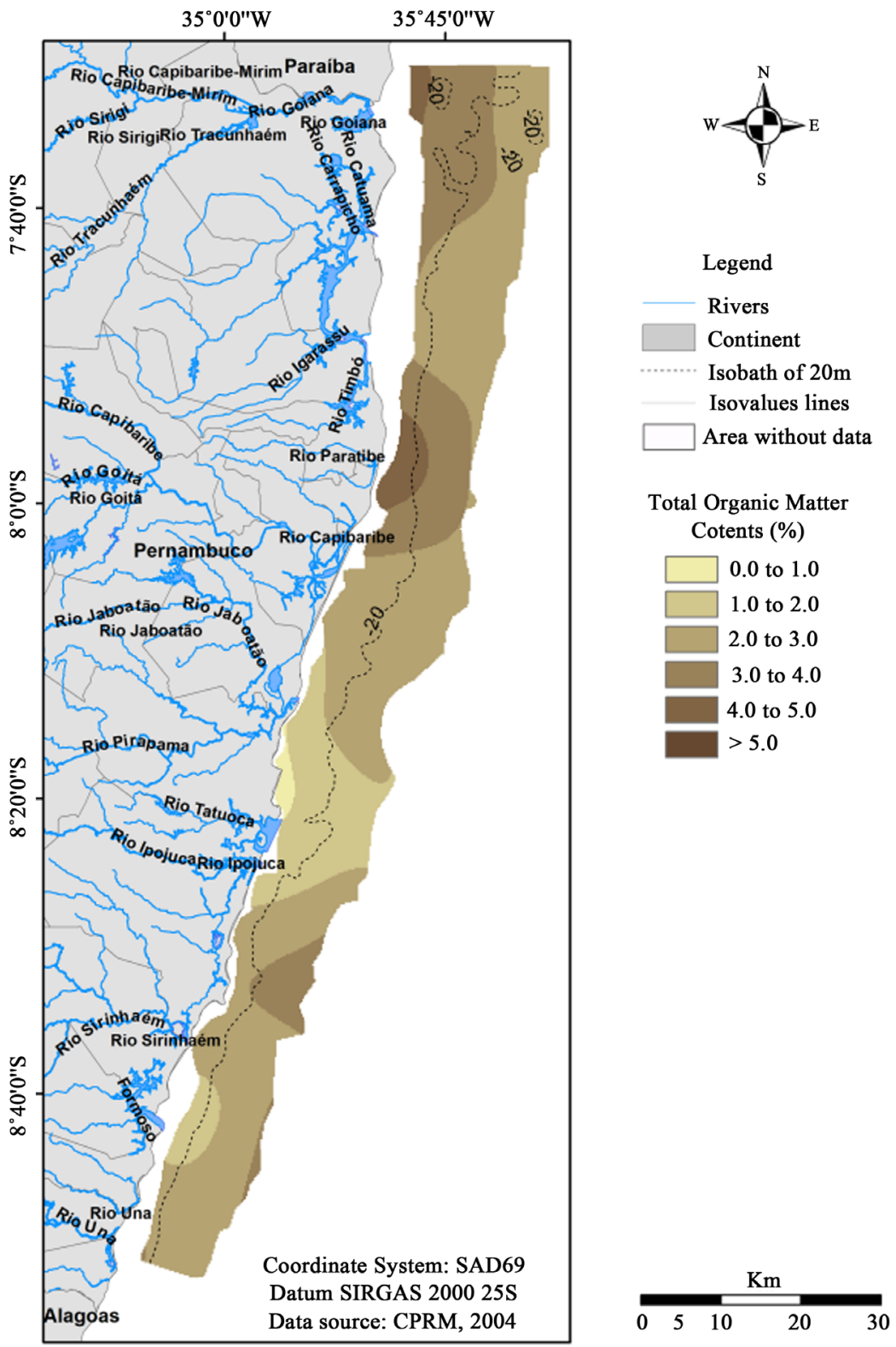

Figure 3. Total Organic Matter (TOM) contents (in \%).

In the central-south portion of PCS are observed contents below $2 \%$ in siliciclastic sediments along the Ipojuca-Tatuoca system (Suape Port area), as previously stated by [32] and [62]. In this sector the inner shelf is narrower (3 km width) due to the presence of granitic Sto Agostinho Cape which stands out 2 $\mathrm{km}$ offshore from the coastline [63]. The low TOM contents and the lower preservation of the $\mathrm{CaCO}_{3}$, would be indicative of a greater hydrodynamics energy of currents to which this sector is subjected. It may be conditioned by the higher depths $(>17 \mathrm{~m})$, very close to the coast, of this portion of the Pernambuco shelf. In fact, [41] state that the hydrodynamics changes according the local seabed morphology, which interferes with the existing flows of the North Brazil Subcurrent. 
The $\mathrm{CaCO}_{3}$ contents ranged from $13.0 \%$ to $99.6 \%$, with a high average of $80.3 \%$. According to [56] classification adapted by [54], bioclastic and biosiliciclastic sediments $\left(\mathrm{CaCO}_{3}>50 \%\right)$, predominate in all PCS, especially in its center-north, and southern portion from Maracaípe river towards Una estuary ( $A P A$ "Costa dos Corais"). The siliciclastic and silicibioclastic sediments are found in the inner shelf adjacent to Capibaribe/Paratibe, Tatuoca e Maracaípe estuaries and in the middle shelf off Ipojuca-Tatuoca estuaries (Suape Port area).

\subsection{Elemental Sedimentary Organic Matter}

The total organic carbon (TOC) (Figure 4) ranged from $0.01 \%$ to $18.08 \%$, with an average of $1.07 \%$. Values below $1.0 \%$ are present in $79.4 \%$ of the samples throughout study area. The TOC contents above $1.0 \%$ are located on depressed features as paleo-valleys or associated to river mouths adjacencies.
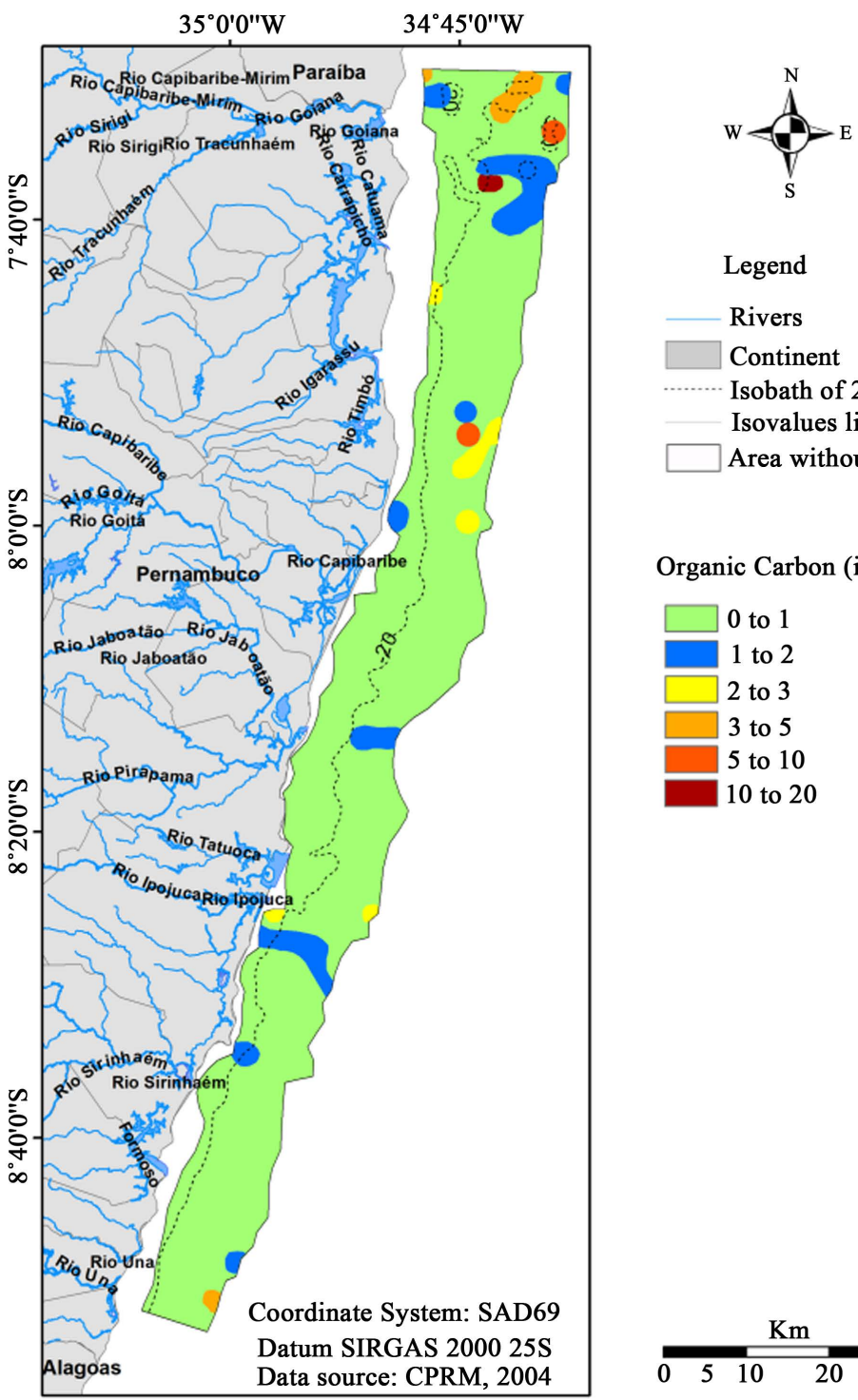

Legend

Rivers

Continent Isobath of $20 \mathrm{~m}$ Isovalues lines Area without data

Organic Carbon (in \%)

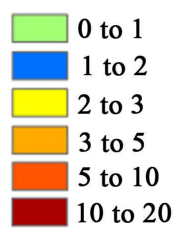

Figure 4. Total Organic Carbon (TOC) contents (in \%). 
The total nitrogen (TN) values (Figure 5) ranged from $0.00 \%$ to $3.49 \%$, with average of $1.09 \%$. The TN was detected in only $52.2 \%$ of the samples collection. For the 71 samples with detection, in $74.6 \%$ the values are below $0.50 \%$. Higher TN contents, analogous to TOC, are associated to the paleochannels, mainly in the most distant areas of the coastline, and are more enriched when compared to other similar shelves [64].

The inputs of carbon in coastal zones are associated to macroalgae, biodeposits and submerged vascularized vegetation decomposition. In the oceans, the material that reaches the bottom is composed of the combination of allocthonous material present in the water column, refractory to microbial decomposition, with the autochthonous biogenic remains. This combination presents values of $0.1 \%$ in the coastal zones and $0.1 \%$ (marine organisms) until $94.0 \%$ (kerogen) in the oceanic regions [10] [60]. According to [60], low TOC contents $(<0.50 \%)$ are characteristic of most of the ocean basins, particularly of the open seas. The sediments near the coastline, inner seas and continental shelves are generally enriched in TOC, where contents from $0.20 \%$ to $0.40 \%$ are not uncommon in these areas. According to [64] the TN contents present similar distribution variations, when compared to the TOC, in a range between $0.00 \%$ to $2.19 \%$, and the concentrations rising adjacent to coastal areas.

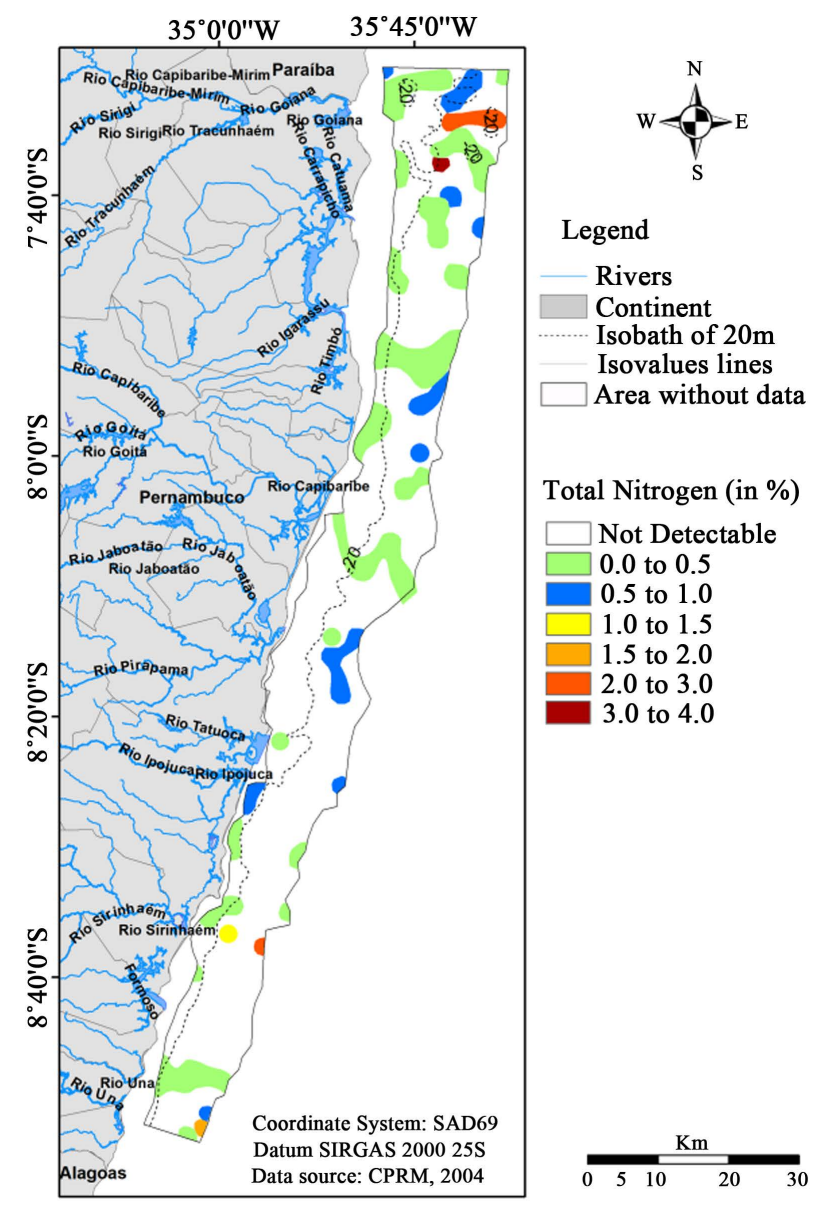

Figure 5. Total Nitrogen (TN) contents (in \%). 
Based on the Spearman correlation results, it is observed that both parameters (TOC and TN) present a significant correlation ( $\mathrm{rs}=0.72$ ) (see Table 1 ). The organic carbon is positively associated to $\mathrm{CaCO}_{3}$ contents ( $\mathrm{rs}=0.18$ ), that according to [65], this positive correlation is an indicator that the organic material present in the samples are from marine origin. In fact, other positive correlations among the studied parameters is also indicative of marine sources for the deposited organic matter found in the majority of Pernambuco continental shelf, ranging from $\mathrm{rs}=0.16$ to 0.28 highlighted in bold in Table 1 .

Overall, the carbon and nitrogen contents of PCS present similarity, when compared with the values observed by [30] for the surface sediments of the inner shelf adjacent to Capibaribe estuarine mouth ( $<<3 \%$; $<0.5 \%)$, for Goiana river mouth region $(\mathrm{C}<1.27 \% ; \mathrm{N}<0.1 \%)$ [31], for Jaboatão-Pirapama inner shelf area $(\mathrm{C}<8.51 \% ; \mathrm{N}<0.54 \%)$ [36], for the mouth of the Formoso river estuary $(\mathrm{C}<2 \%)[66]$, and in the insular shelf adjacent to Fernando de Noronha Island $(\mathrm{C}<3.4 \%$ e $\mathrm{N}<0.9 \%)$ [67]. Some water column values agree with the studied shelf deposits of SOM characteristics, as observed by [33] adjacent to Capibaribe estuarine mouth ( $\mathrm{C}$ varying from 475 to $975 \mu \mathrm{M}$; in the case of nitrogen compounds $\mathrm{N}-\mathrm{NO}^{2}+\mathrm{N}-\mathrm{NO}^{3}$ from 1.5 to $\left.6.9 \mu \mathrm{M}\right)$ and [34] in the estuarine plumes of Capibaribe and Jaboatão rivers ( $\mathrm{C}$ average $<3.2 \%$, N average < $0.92 \%)$. The presented data when compared to the work of [27] is observed that the contents are coherent for a tropical region and for the shelf adjacent for Amazon River the contents are around $\mathrm{C}<0.8 \%$ and $\mathrm{N}<0.2 \%$. In the case of the temperate zone (Gulf of Mexico), the values are slightly higher $(\mathrm{C}<1.5 \%$ and $\mathrm{N}$ $<0.2 \%$ ), and in the arctic region (Mackenzie River and shelf) the $\mathrm{C}$ values reach $17 \%$, prevailing $\mathrm{C}<2 \%$ and the $\mathrm{N}$ is similar to these other climate zones.

When comparing the studies developed by [30] [31] [36] [66] [68] in the line of this research data, is observed that these estuarine regions have major potential for SOM retention than the PCS. The values of inner estuarine portions are higher $(\mathrm{C}<9 \%$ and $\mathrm{N}<1 \%)$, decreasing in the shelf direction. Reference [37] described that the positive features of relief (submerged beach-rocks lines) and negative (paleochannels and incised valleys) influence the sedimentary material inputs and deposition in the north PCS. References [69] [70] show that the presence of deeper and depressed areas provide more favorable environment for the deposition of finer materials. This transport mechanism leads the finer sediments to be carried to external shelf areas distant from the coast, allowing the presence of sediments containing $\mathrm{C}>10 \%$ e $\mathrm{N}<4 \%$ in the PCS middle shelf.

\subsection{Sedimentary Organic Matter Origin}

The C/N elemental ratio is a tool widely employed to classify several types of SOM present in aquatic environments [71]. This classification is possible, since the ratio can provide information that allows to indicate, the origin of the SOM, distinguishing the marine and terrestrial sources. According to [72] the organic matter of continental origin may be identified in marine sediments by means of 
the high values of carbon and low protein contents $(<10 \%)$, thus resulting in a high $\mathrm{C} / \mathrm{N}$ ratio $(>12)$, classifying the terrestrial inputs.

The $\mathrm{C} / \mathrm{N}$ ratio values oscillated between 0.05 and 17.8, with average of 3.5 , and in $98.6 \%$ of the samples the values are below 6 . Based on the classification proposed by [11] [21], autochthonous origin material prevails, of marine origin, and with the presence of continental material carried for deeper shelf portions.

The study carried out in sediments by [30] for Capibaribe estuary mouth area measured $\mathrm{C} / \mathrm{N}$ values between 4 and $>12$, [31] for Goiana river inlet observed values of $\mathrm{C} / \mathrm{N}<13.6$ and [36] for the mouth of Jaboatão-Pirapama estuary observed values of $\mathrm{C} / \mathrm{N}<25.5$. Reference [34] for Capibaribe and Jaboatão-Parapama estuarine plumes, observed $\mathrm{C} / \mathrm{N}<12.8$ and $<27.9$ respectively. Reference [27] classified the material of the Gulf of México and from river Amazon adjacent shelf as biogenic material, composed by proteins $(\mathrm{C} / \mathrm{N} \approx 5)$. The values of cited works are similar of those observed in the present study. According to [34] in the water column and [36] in sediments, the values of $\mathrm{C} / \mathrm{N}$ ratio increase in the rainy season according to the rise of the coastal zone inputs that stimulates the primary production.

The $\delta^{13} \mathrm{C}$ contents varied from $-31.5 \mathrm{PDB} \%$ to $-14.4 \mathrm{PDB} \%$, with an average of $-21.1 \mathrm{PDB} \%$ (Figure 6). For the 106 samples that the $\delta^{13} \mathrm{C}$ were measured, $53.8 \%$ are more enriched than -21.0 PDB\%o. Based on the classifications proposed by [11] [21] [27] [28] [29] and when compared to the values observed in the coastal zones of the study area by [30] [32] [33] [34] [36] [66] [68], a classification was performed related to SOM origin which is shown in the PCA. There is a marine material prevalence ( $>-21.0 \% \mathrm{PDB}$ ), followed by a wide presence of marine material with continental contributions (between $-21.0 \mathrm{PDB} \%$ and -24.0 PDB\%), with the presence of mixed marine and continental SOM $(-24.0$ PDB\%o e -26.0 PDB\%o), and characteristics of terrestrial origin $(<-26.0$ PDB\%o).

The $\delta^{15} \mathrm{~N}$, which were measured in 72 samples, ranged from -14.6 Air\%o a 24.6 Air\%o, with an average of 5.8 Air\%o and prevailing values of $<8$ Air\%o, in $76.4 \%$ of the sampling stations (Figure 7). The negative values were located on the paleochannels, one to the north, and the other to the south of the study area. The classification shown in Figure 7 was established based in the aforementioned literature. By means of this indicator were verified the predominance of mixed material (3 Air\%o to 8 Air\%o) and organic material of marine origin ( $>8$ Air\%o).

Based on the study developed by [34] [41] for the PCS water masses and the estuarine plumes of Capibaribe and Jaboatão rivers, respectively, is possible to observe that the emissions of SOM regulates the biogeochemical cycles that occur in the coastal zone, mainly in the major primary production periods. Reference [41] shows that due to the meteoceanographic conditions, the local hydrodynamics and the reduced terrestrial inputs, the continental influence do not reach great areas off the coast, being limited to the area immediately adjacent the estuarine mouths. In this way the continental contributions are more expressive 

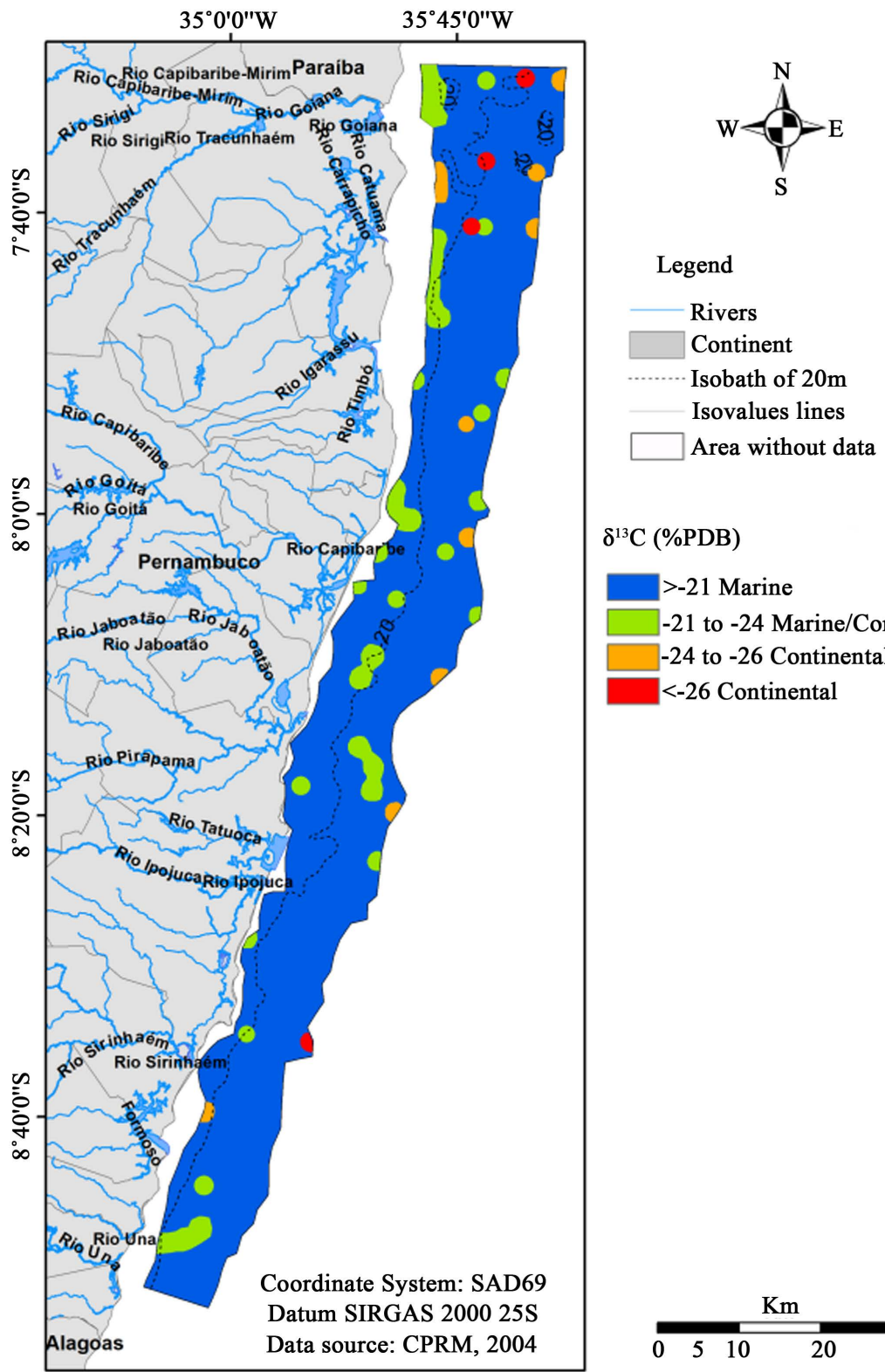

$\delta^{13} \mathrm{C}(\% \mathrm{PDB})$

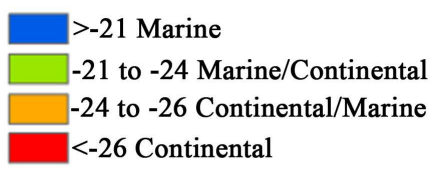

Figure 6. The $\delta^{13} \mathrm{C}$ ratio contents in PCS (in PDB\%o).

during the rainy period, carrying to the coast the natural origin material together with the SOM from the anthropogenic emissions sources.

Reference [69] stated that the linear depressed features that cross the Pernambuco southern shelf were formed as a result of the Pleistocene sea level fluctuations, with the drowning of the ancient paleo-valleys channels of the rivers. These paleochannels and incised valleys present correspondence with the modern coastal rivers as Formoso River estuarine system. As it is a starving shelf, with reduced terrigenous input [73], the PCS paleochannels are preserved by the low sedimentary input that reaches the coast. These negative features, due to the lower hydrodynamic present in them, act as traps of fine sediments [69] [74] [75] [76] [77] [78]. 

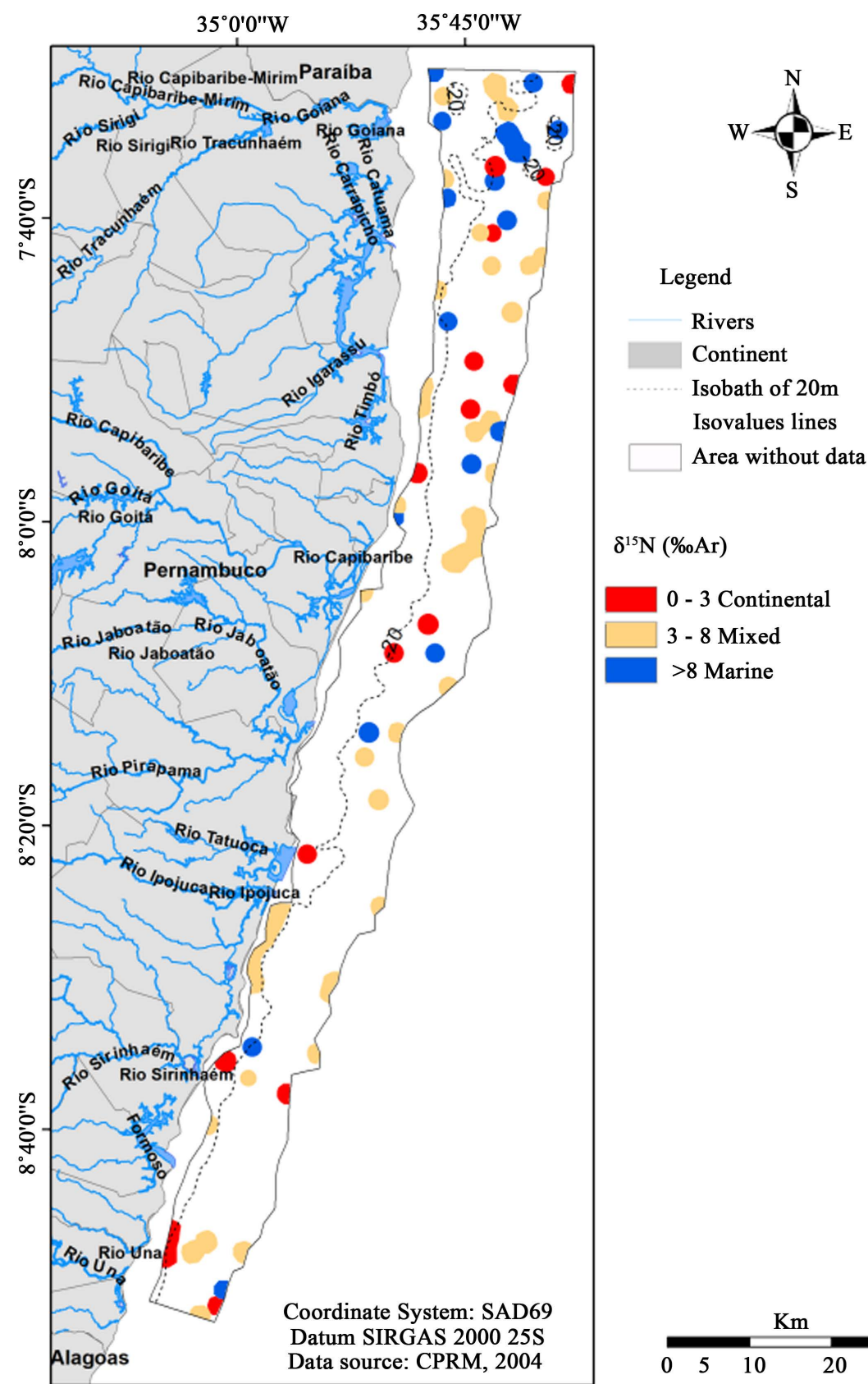

$\delta^{15} \mathrm{~N}(\% \mathrm{Ar})$

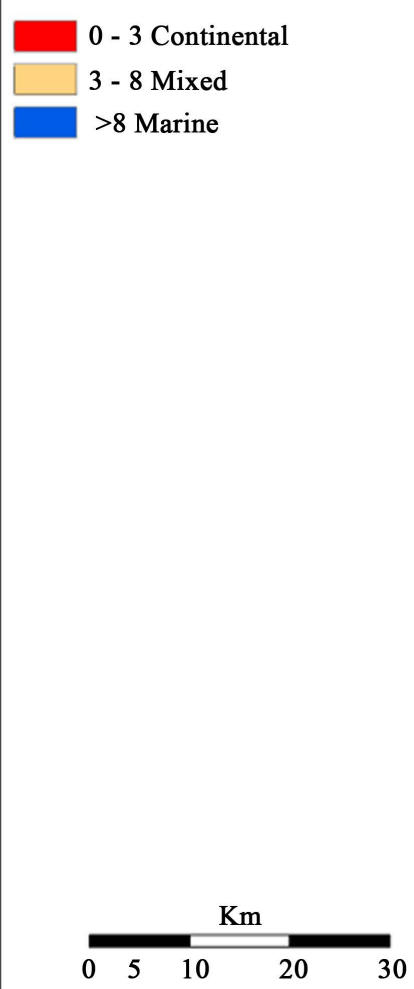

Figure 7. The $\delta^{15} \mathrm{~N}$ ratio contents in PCS (in AIR\%o).

According to these studies, it is inferred that the terrestrial material observed in these channels, are product of the carrying and deposition of the coastal material, which possibly occurred at periods of higher continental contributions. The patches of typical material that would be tracers of SOM of continental origin are spatially associated, according to Figure 2, Figure 3 and Figure 7, of the estuaries of Goiana, Capibaribe and Una rivers, and Igarassu estuarine-lagoonal system. The first three estuaries, excepting the Ipojuca-Tatuoca System, are the larger translittoral rivers of Pernambuco State [40]. These patches of fine sediments with allochthonous SOM occurs mostly in the coastal sampling stations, 
being directly associated to these water streams inputs. Although these rivers have low average flow $\left(-11 \mathrm{~m}^{3} \cdot \mathrm{s}^{-1}\right.$ to $\left.50 \mathrm{~m}^{3} \cdot \mathrm{s}^{-1}\right)$ [30] [79], they would have the capacity to export terrestrial material, and to print this siliciclastic sedimentation, even if locally, on the inner shelf adjacent to its mouths.

\subsection{Geochemical Facies Classification of Pernambuco Shelf}

The parameters used in the statistical analysis for the determination of geochemical facies were depth, $\delta^{13} \mathrm{C}$ isotopic ratio and the percent of gravel, sand, mud, TOM, $\mathrm{CaCO}_{3}$ and carbon. The nitrogen data, elemental and isotopic, were not included in the analysis for presenting low levels, below the quantity necessary for detection. Thus, the absence of TN and $\delta^{15} \mathrm{~N}$ data would be considered as geochemical qualified parameters during the execution of the statistical analyses by the software, promoting a false interpretation of the data collection. Although the TN and $\delta^{15} \mathrm{~N}$ were reconsidered for the description and further detailing of observed geochemical facies.

In this way, 6 facies were obtained, which the two main PCA eigenvectors comprise $48.7 \%$ of the total information of the variants (Table 2). In Table 3 is possible to observe that in both components, the depth selected the samples positively, while the gravel and calcium carbonate influenced negatively.

In Figure 8 are the exposed graphic and the respective eigenvectors.

Based on the PCA, 6 geochemical facies were established (Table 4):

- The Facies 1-are samples that varied from siliciclastic to bioclastic, with the predominance of biosiliciclastic, mud to sand granulation, presenting around $5.0 \%$ of TOM on average, TN $(<0.36 \%)$ and TOC below $1.20 \%$ with SOM of marine origin $\left(\delta^{13} \mathrm{C}:-21.2 \mathrm{PDB} \%\right.$; $\mathrm{C} / \mathrm{N}: 2.9$ in average), located around $14 \mathrm{~m}$ depth, off the Capibaribe, Sirinhaém e Una estuaries.

Table 2. The PCA eigenvectors.

\begin{tabular}{cccc}
\hline Principal Components & Autovalues & \% Variation & \% Cumulative Variation \\
\hline 1 & 2.07 & 25.9 & 25.9 \\
2 & 1.83 & 22.8 & 48.7 \\
\hline
\end{tabular}

Table 3. Principal components calculated by means of the PCA.

\begin{tabular}{ccc}
\hline Proxies & PC1 & PC2 \\
\hline Depth & 0.406 & 0.137 \\
Gravel (\%) & -0.532 & -0.335 \\
Sand (\%) & 0.262 & -0.359 \\
Mud (\%) & 0.077 & 0.564 \\
TOM (\%) & -0.284 & 0.468 \\
$\mathrm{CaCO}_{3}$ & -0.564 & -0.120 \\
$\mathrm{TOC} \mathrm{( \% )}$ & -0.245 & 0.312 \\
$\delta^{13} \mathrm{C} \mathrm{PDB} \mathrm{( \% )}$ & 0.138 & -0.300 \\
\hline
\end{tabular}


Table 4. Geochemical facies description of Pernambuco continental shelf.

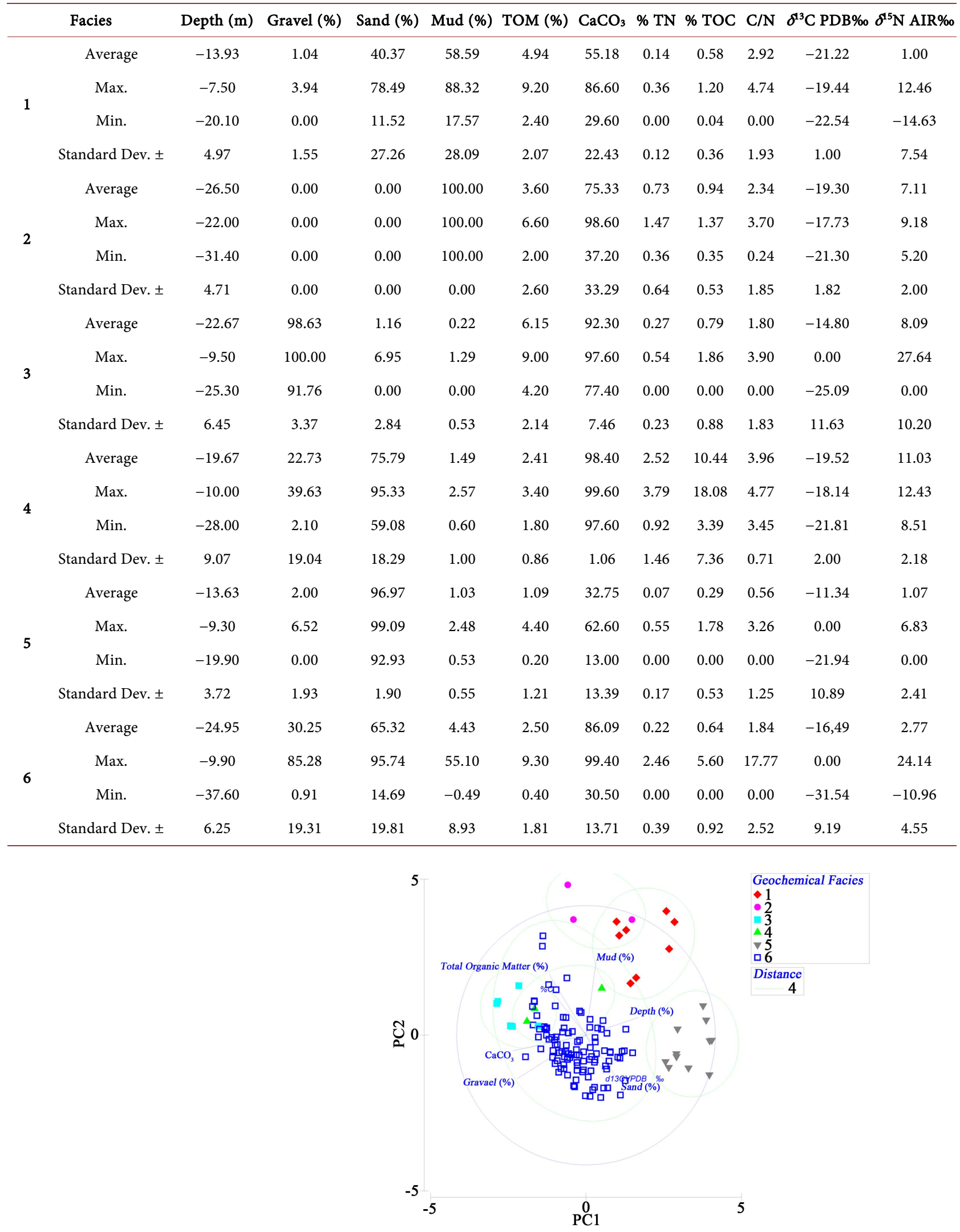

Figure 8. The PCA vectors and graphic representation of studied parameters in the PCS. 
- The Facies 2-is composed by bioclastic mud, of marine origin ( $\delta^{13} \mathrm{C}$ : -19.3 $\mathrm{PDB} \%$; C/N: 2.3 in average) with average TOM contents of $3.6 \%$, values of TOC and TN below $1.37 \%$ and $1.47 \%$, respectively, located at an average depth of $26 \mathrm{~m}$, off the Sirinhaém river estuary.

- The Facies 3-is formed by bioclastic gravel, with higher average of TOM contents $(6.15 \%)$, of marine origin $\left(\delta^{13} \mathrm{C}:-14.8 \mathrm{PDB} \%\right.$; $\mathrm{C} / \mathrm{N}: 1.8$ in average), with TN below $0.54 \%$ and TOC $<1.0 \%$. The average depth is $22.7 \mathrm{~m}$, located in the northern PCS.

- The Facies 4-is composed by bioclastic sands with high levels of TOC (10.4\% in average) and TN (2.52\% in average) in its composition of marine origin ( $\delta^{13} \mathrm{C}$ : $-19.5 \mathrm{PDB} \%$; $\mathrm{C} / \mathrm{N}: 4$ in average), limited to a two specific points in PCS, whose high organic contents can be associated with high local biogenic production, located off Goiana estuary in the middle shelf.

- The Facies 5-varies from siliciclastic to silicibioclastic sands, with low TOM contents (1.09\% in average), and TOC and TN contents below $0.55 \%$ and $1.78 \%$ respectively, and SOM of marine origin $\left(\delta^{13} \mathrm{C}-11.3 \mathrm{PDB} \%\right.$; $\mathrm{C} / \mathrm{N}$ : 0.6 in average). This facies is located mainly adjacent to the Santo Agostinho Cape in the estuarine system of Ipojuca-Tatuoca (Suape Port area) [32], whose granitic rocks of Cabo Granitic Suite [63] would be the main sources of these siliciclastic deposits that occur on the PCS.

- The Facies 6-prevailed over all other facies, being composed by bioclastic sands and gravels, TOM with average of $2.5 \%$, of marine origin $\left(\delta^{13} \mathrm{C}:-16.5\right.$ $\mathrm{PDB} \%$; $\mathrm{C} / \mathrm{N}: 1.8$ in average $)$ and, in general, low contents of TOC $(0.64 \%$ in average) and average values of TN of $0.22 \%$.

This comparatively higher nitrogen average contents compared to carbon, above the C: $\mathrm{N}$ ratio of the Redfield relation (106:16) [71], may be the major indicator of local biogenic production in the contribution of organic matter deposited in the surface sediments, in a large part of PCS, see the Facies 6 in Figure 9. This proportion of $\mathrm{C}: \mathrm{N}$ is reflected in the low $\mathrm{C} / \mathrm{N}$ ratios, indicative of values derived from marine phytoplankton and zooplankton [11] [80], as well as the most enriched contents of $\delta^{13} \mathrm{C}$ ratio $(-16.5 \mathrm{PDB} \%)$. This factor, added to the low terrestrial coastal supply, gives the predominant character of the PCS, classified as a starving shelf [73], with biogenic sandy-gravel composition, and low to medium organic contents of marine origin.

On the other hand, when the TOM contents are very low due to the moderate to high hydrodynamics of currents in the region, as observed by [41] for PCS and [55] for Rio Grande do Norte shelf, the nitrogen would be more easily recycled in the early stages of oxidation of organic matter after being deposited [81]. This conditioning results in the large number of samples $(n=65)$ in which the TN was not detected $(0.00 \%)$.

Despite the low TN detection, in fact, the PCS organic matter is formed mainly by marine algae, and secondarily from marine particulate and dissolved organic carbon (DOC) and traces of freshwater (DOC and POC), according $\delta^{13} \mathrm{C}$ 

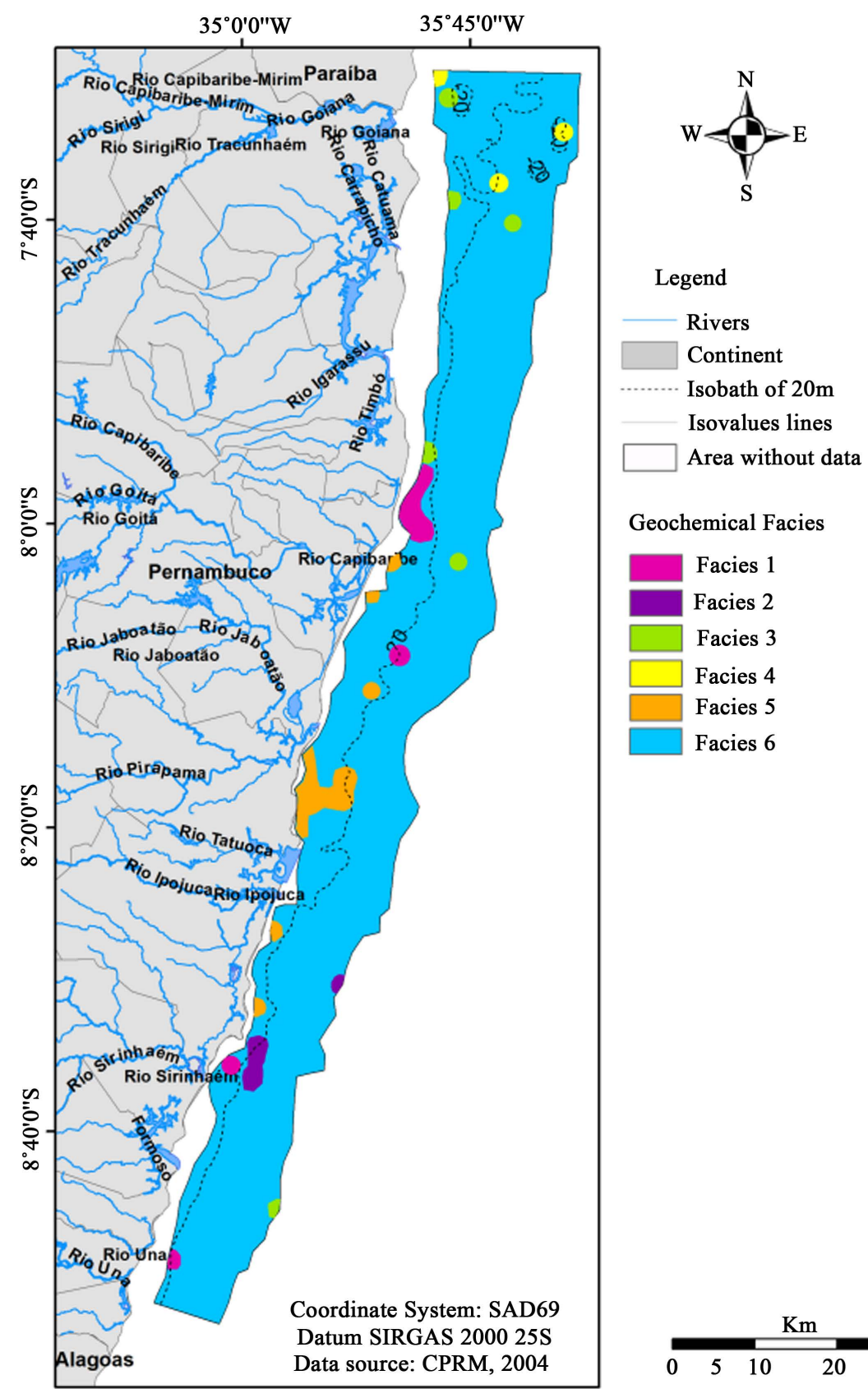

Geochemical Facies

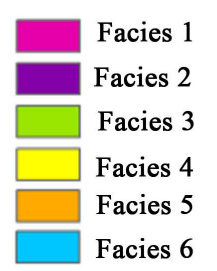

Figure 9. The geochemical Facies in PCS.

versus $\mathrm{C} / \mathrm{N}$ graphic (Figure 10). In the case of the plot of the $\delta^{13} \mathrm{C}$ versus $\delta^{15} \mathrm{~N}$ (Figure 11), the surface sediments were also influenced by freshwater phytoplankton, terrestrial superior plants $\left(\mathrm{C}_{3}\right)$ and mostly by marine and estuarine organic matter sources.

Observing the facies, it is evident the behavior already mentioned, that the Coastal Water (CW), with terrestrial sediments and organic matter, interacts with the Tropical Water (TA) [41]. In which facies 1 and 5 are more related to estuaries mouths and the associated paleo-valleys, whose mixed and terrestrial contributions can be observed in the studies carried out by [30] [31] [32] [36] 
[62] [66] [68]. This demonstrates how the estuarine systems act in the retention of SOM, and in episodes of huge fluvial inputs, could export and reach offshore portions of the shelf. The paleo-valleys would be the natural conducts and connectors of these shelf terrestrial material deposits, as proposed by [69]. References [33] [34] show that the process that occurs in the water column are the result of the relationship between the several activities carried out in the marine environment-discharges of several types of effluents-with the environmental and meteoceanographic variants-precipitation, seasonality, physiography, currents-which result in the deposited material. The facies 6 predominate in whole study area (Figure 12). This indicates the large influence of oceanic waters observed by [41] on the Pernambuco Continental Shelf.

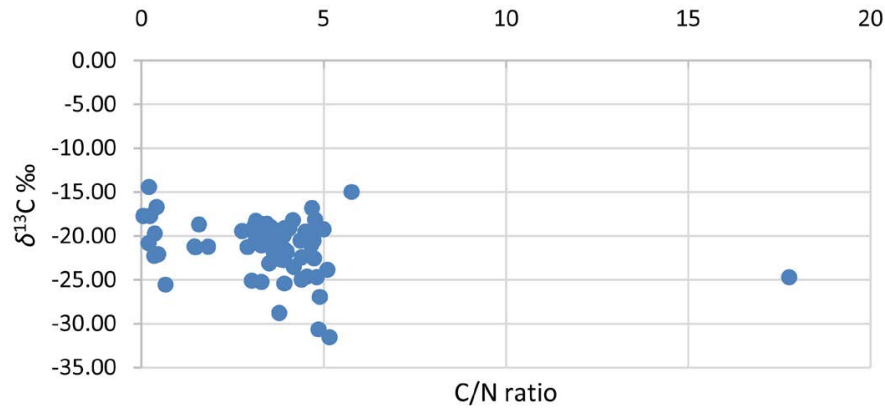

Figure 10. Graphic characterization of SOM sources $\left(\delta^{13} \mathrm{C} \times \mathrm{C} / \mathrm{N}\right.$ ratio $)$ according to [82].

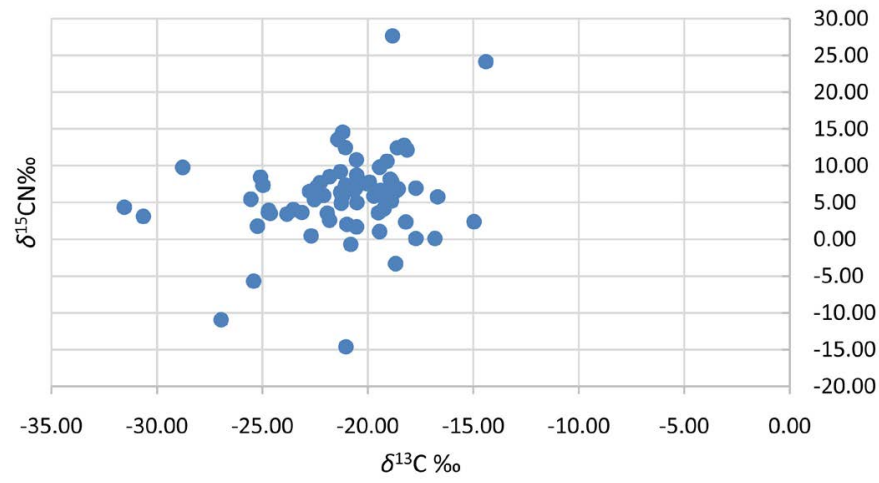

Figure 11. Graphic characterization of SOM sources $\left(\delta^{13} \mathrm{C} \times \delta^{15} \mathrm{~N}\right)$ according to [82].

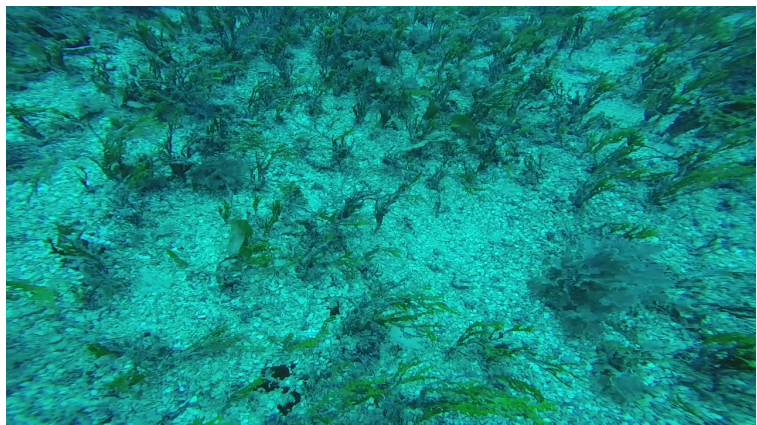

Figure 12. Seabed view of geochemical Facies 6 characteristics in the middle shelf off Jaboatão Estuary at $25 \mathrm{~m}$ depth (Photography of Ernesto Domingues, $6^{\text {th }} \mathrm{June} / 2018$ ). 


\section{Conclusions}

Based on the data of the present work, it is observed that the inner and middle Pernambuco Continental Shelf (PCS) have a predominance of poorly sorted material of autochthonous bioclastic sandy-gravel origin, with low to medium organic matter contents of marine origin, along its entire length.

The presence of materials of mixed and continental origin is specially located in patches, in the inner shelf region adjacent to the estuarine mouths of Capibaribe, Sirinhaém and Una systems, and off Santo Agostinho Cape (Ipojuca and Tatuoca estuaries). The data shows that due to the factors such as physiography and meteoceanographical conditionings, the terrestrial origin material could be carried to offshore, as from the $20 \mathrm{~m}$ isobath.

The facies 6 is the geochemical class that predominates throughout the area, shows an environment with moderate to high hydrodynamic energy, reflected by the poorly sorted bioclastic sandy-gravel cover, with sedimentary organic matter of marine origin.

The facies 2, 3 and 4 are also distributed in patches of muds and gravels of biogenic SOM origin.

Finally, the facies 1 and 5 represent the influence of terrestrial inputs that could bring pollutants and contaminants adsorbed in its composition and the adjacent coastal zones exports for the marine PCS areas. However, it lacks comparative regional studies of sedimentary theme, geochemical and marine geochemistry for further details.

\section{Acknowledgements}

The authors of this work thank the Geological Service of Brazil-CPRM, through the project "Marine Granulates-GRANMAR Pernambuco", by the sampling expeditions and samples packaging. Our sincere thanks to CAPES for the PhD fellowship support. Our thanks are also indebted to Hortência M. B. de Assis and team (CPRM-PE), Ronaldo G. Bezerra (CPRM-PE), Carlos Fernando de A. Soares Júnior (UFC), Prof. George Satander Sá Freire (UFC) and MsC. Liza Ellen E. Oliveira (UFPE) by the availability of "in-situ" collected data, and the partial performed sedimentary analyses. We thank Marine Geology and Geophysical Laboratory (LGGM-UFPE), Geological Oceanography Laboratory (Labogeo-UFPE), for the infrastructure, and support for carrying out the geochemical analyses. Finally, our gratitude to the Prof. Valderez Ferreira from Granite Studies Group-Stable Isotope Laboratory-NEG-LABISE-of University Federal of Pernambuco.

\section{Conflicts of Interest}

The author declares no conflicts of interest regarding the publication of this paper.

\section{References}

[1] Heezen, B.C., Glass, B. and Menard, H.W. (1966) The Manihiki Plateau. Deep Sea 
Research and Oceanographic Abstracts, 13, 445-458. https://doi.org/10.1016/0011-7471(66)91079-5

[2] IHO (2008) Standardization of Undersea Feature Names: Guidelines Proposal form Terminology. 4th Edition, International Hydrographic Organization and Intergovernmental Oceanographic Commission, Monaco, p. 32.

[3] Coutinho, P.N. (1996) Levantamento do Estado da Arte da Pesquisa dos Recursos Vivos Marinhos do Brasil-Oceanografia Geológica. Região Nordeste. Programa REVIZEE. Ministério do Meio Ambiente, dos Recursos Hídricos e da Amazônia Legal (MMA). Brasília, 97 p.

[4] Harris, P.T., Macmillan-Lawler, M., Rupp, J. and Baker, E.K. (2014) Geomorphology of the Oceans. Marine Geology, 352, 4-24. https://doi.org/10.1016/j.margeo.2014.01.011

[5] Camargo, J.M.R. (2016) Geodiversidade e Paisagens Submersas de uma Plataforma Continental Tropical no Nordeste do Brasil. PhD Thesis, Federal University of Pernambuco, Recife, $171 \mathrm{p}$.

[6] Rebouças, R.C. (2010) Sedimentação Holocênica da Plataforma Continental de Salvador-BA. Salvador-Bahia. PhD Thesis, Federal University of Bahia, Salvador, 90 p.

[7] Ponzi, V.R.A. (2004) Sedimentação marinha. In: Baptista Neto, J.A., Ponzi, V.R.A. and Sichel, S.E., Eds., Introdução à Geologia Marinha, Ed. Interciência, Rio de Janeiro, 219-241.

[8] Thurman, H.V. and Burton, E.A. (1997) Introductory Oceanography. Prentice Hall, New York, 544 p.

[9] Garrison, T. (2010) Fundamentos de Oceanografia. Cengage Learning, São Paulo, $426 \mathrm{p}$.

[10] Tyson, R.V. (1995) Sedimentary Organic Matter. Chapman \& Hall, London, 589 p. https://doi.org/10.1007/978-94-011-0739-6

[11] Meyers, P.A. (1997) Organic Geochemical Proxies of Paleoceanography, Paleolminologic and Paleoclimatic Processes. Organic Geochemistry, 27, 213-250. https://doi.org/10.1016/S0146-6380(97)00049-1

[12] Barcellos, R.L. and Furtado, V.V. (2006) Organic Matter Contents and Modern Sedimentation at São Sebastião Channel, São Paulo State, South-Eastern Brazil. Journal of Coastal Research, 39, 1073-1077.

[13] Bouillon, S., Raman, A.V., Dauby, P. and Dehairs, F. (2002) Carbon and Nitrogen Stable Isotope Ratios of Subtidal Benthic Ecosystem (Andhra Pradesh, India). Estuarine, Coastal and Shelf Science, 54, 901-913. https://doi.org/10.1006/ecss.2001.0864

[14] Dias, J.C. and Lima, W.N. (2004) Comparação de Métodos para a Determinação de Matéria Orgânica em Amostras Ambientais. Revista Científica da UFPA, 4(1).

[15] Souza, J.L., Prezotti, L.C. and Guarçoni, M. (2012) Potencial de Sequestro de Carbono em Solos Agrícolas sob Manejo Orgânico para Redução da Emissão de Gases de Efeito Estufa. Idesia (Arica), 30, 7-15. https://doi.org/10.4067/S0718-34292012000100002

[16] Galloway, J.N., Aber, J.D., Erisman, J.W., Seitzinger, S.P., Howarth, R.W., Cowling, E.B. and Cosby, B.J. (2003) The Nitrogen Cascade. Bioscience, 53, 341-356. https://doi.org/10.1641/0006-3568(2003)053[0341:TNC]2.0.CO;2

[17] Santoro, A.E. (2010) Microbial Nitrogen Cycling at the Saltwater-Freshwater Interface. Hydrogeology Journal, 18, 187-202. https://doi.org/10.1007/s10040-009-0526-Z

[18] Peterson, B.J. and Fry, B. (1987) Stable Isotopes in Ecosystem Studies. Annual Re- 
view of Ecology and Systematics, 18, 293-320. https://doi.org/10.1146/annurev.es.18.110187.001453

[19] Dawson, T.E. and Brooks, P.D. (2001) Fundamentals of Stable Isotope Chemistry and Measurement. In: Unkovich, M., et al., Eds., Stable Isotope Techniques in the Study of Biological Processes and Functioning of Ecosystems, Kluwer Academic Publisher, Dordrecht, cap. I, 1-18. https://doi.org/10.1007/978-94-015-9841-5 1

[20] Müller, P.J. (1977) CN Ratios in Pacific Deep-Sea Sediments: Effect of Inorganic Ammonium and Organic Nitrogen Compounds Sorbed by Clays. Geochimica et Cosmochimica Acta, 41, 765-776. https://doi.org/10.1016/0016-7037(77)90047-3

[21] Bordovsky, O.K. (1965) Accumulation of Organic Matter in Bottom Sediments. Marine Geology, 3, 33-82. https://doi.org/10.1016/0025-3227(65)90004-6

[22] McLeod, E., Chmura, G.L., Bouillon, S., Salm, R., Björk, M., Duarte, C.M., Lovelock, C.E, Schlesinger, W.H. and Silliman, B.R. (2011) A Blueprint for Blue Carbon: Toward an Improved Understanding of the Role of Vegetated Coastal Habitats in Sequestering $\mathrm{CO}_{2}$. Frontiers in Ecology and the Environment, 9, 552-560. https://doi.org/10.1890/110004

[23] Krishna, M.S., Naidu, S.A., Subbaiah, C.V., Gawade, L., Sarma, V.V.S.S. and Reddy, N.P.C. (2015) Sources, Distribution and Preservation of Organic Matter in a Tropical Estuary (Godavari, India). Estuaries and Coasts, 38, 1032-1047. https://doi.org/10.1007/s12237-014-9859-5

[24] Yamamuro, M., Kayanne, H. and Yamano, H. (2003) $\delta^{15} \mathrm{~N}$ of Seagrass Leaves for Monitoring Anthropogenic Nutrient Increases in Coral Reef Ecosystems. Marine Pollution Bulletin, 46, 452-458. https://doi.org/10.1016/S0025-326X(02)00463-0

[25] Yamamuro, M. and Kamiya, H. (2014) Elemental (C, N, P) and Isotopic ( $\left.\delta^{13} C, \delta^{15} \mathrm{~N}\right)$ Signature of Primary Producers and their Contribution to the Organic Matter in Coastal Lagoon Sediment. Landscape and Ecological Engineering, 10, 65-75. https://doi.org/10.1007/s11355-013-0219-6

[26] Chester, R. and Riley, J.P. (1978) Chemical Oceanography. Academic Press Inc. Ltd., London, Vol. 7, 508 p.

[27] Ruttenberg, K.C. and Goñi, M.A. (1997) Phosphorus Distribution, C:N:P Ratios, and $\delta^{13} \mathrm{C}$ in Arctic, Temperate and Tropical Coastal Sediments: Tolls for Characterizing Bulk Sedimentary Organic Matter. Marine Geology, 139, 123-145. https://doi.org/10.1016/S0025-3227(96)00107-7

[28] Stein, R. (1991) Accumulation of Organic Carbon in Marine Sediments. Results from the Deep-Sea Drilling Project/Ocean Drilling Program. In: Bhattacharji, S., Friedman, G.M., Neugebauer, H.J. and Seilacher, A., Eds., Lecture Notes in Earth Sciences, Springer, Berlin, $217 \mathrm{p}$.

[29] Lamb, A.L., Wilson, G.P. and Leng, M.J. (2006) A Review of Coastal Palaeoclimate and Relative Sea-Level Reconstructions Using $\delta^{13} \mathrm{C}$ and $\mathrm{C} / \mathrm{N}$ Ratios in Organic Material. Earth-Science Reviews, 75, 29-57.

https://doi.org/10.1016/j.earscirev.2005.10.003

[30] Oliveira, T.S., Barcellos, R.L., Schettini, C.AF. and Camargo, P.B.D. (2014) Processo Sedimentar Atual e Distribuição da Matéria Orgânica em um Complexo Estuarino Tropical, Recife, PE, Brasil. Revista de Gestão Costeira Integrada, 14, 399-412. https://doi.org/10.5894/rgci470

[31] Barcellos, R.L., Alves, C.S. and Fetter-Filho, A.F.H. (2016) Geoquímica e Dinâmica Sedimentar do Sistema Estuarino do Rio Goiana. NEA-Edições, Saarbrücken, Alemanha. v. 1, 89 p. 
[32] Barcellos, R.L., Santos, L.D., Oliveira, T.R.S., Oliveira, T.S. and Silva, J.C.A. (2018) Análise dos Componentes da Fração Arenosa como Indicadores Ambientais no Sistema Costeiro Associado ao Complexo Industrial-Portuário de Suape (PE). Parcerias Estratégicas (Impresso), 46, 159-168.

[33] Guenther, M., Araújo, M., Flores-Montes, M., Gonzalez-Rodriguez, E. and Neumann-Leitão, S. (2015) Eutrophication Effects on Phytoplankton Size-Fractioned Biomass and Production at a Tropical Estuary. Marine Pollution Bulletin, 91, 537-547. https://doi.org/10.1016/j.marpolbul.2014.09.048

[34] Travassos, R.K., Flores-Montes, M.J., Costa, B.V.M. and Silva-Júnior, J.M. (2016) The Influence of Urban Effluents on the Elemental C/N Ratio in a Tropical Coastal Area of Northeastern Brazil. Journal of Coastal Research, 75, 168-172. https://doi.org/10.2112/SI75-034.1

[35] Manso, V.A.V., Correa, I.C.S. and Guerra, N.C. (2003) Morfologia e Sedimentologia da Plataforma Continental Interna entre as Praias Porto de Galinhas e Campos-Litoral Sul de Pernambuco, Brasil. Pesquisas em Geociências, 30, 17-25. https://doi.org/10.22456/1807-9806.19587

[36] Barcellos, R.L., Flores-Montes, M.J., Alves, T.M.F. and Camargo, P.B. (2016) Modern Sedimentary Processes and Seasonal Variations of Organic Matter in an Urban Tropical Estuary, Jaboatão River (PE), Brazil. Journal of Coastal Research, 75, 38-42. https://doi.org/10.2112/SI75-008.1

[37] Melo, M.C.S.S., Barcellos, R.L., Oliveira, L.E.E. and Manso, V.A.V. (2019) Aspectos Sedimentológicos e Batimétricos da Plataforma Continental Norte de Pernambuco-Brasil. Estudos Geológicos, 29, 17-30.

[38] Passavante, J.Z.O. and Feitosa, F.A.N. (1995) Produção Primária Do Fitoplâncton Da Plataforma Continental de Pernambuco (Brasil): Àrea de Piedade. Boletim Técnico Científico do CEPENE, 3, 7-22.

[39] Baptista-Neto, J.A, Ponzi, V.R.A. and Sichel, S.E. (2004) Introdução à Geologia Marinha. Interciência, Rio de Janeiro, $279 \mathrm{p}$.

[40] Manso, V.A.V., Coutinho, P.N., Pedrosa, F.J., Macedo, R.J., Silva, A.C., Gois, L.A., Barcellos, R.L., Arruda, S. D. D., Soares-Junior, C.F.A., Madruga-Filho, J. D., Arrais, M.M.C., Madruga, M.M.D. (2018). Pernambuco. In: Muehe, D., Org., Panorama da Erosão Costeira no Brasil, Pernambuco, Biblioteca do Ministério do Meio Ambiente, Brasília, 345-380.

[41] Domingues, E.D.C., Schettini, C.A.F., Truccolo, E.C. and Oliveira Filho, J.C.D. (2017) Hydrography and Currents on the Pernambuco Continental Shelf. RBRH, 22, e43. https://doi.org/10.1590/2318-0331.0217170027

[42] Nimer, E. (1979) Climatologia do Brasil. Instituto Brasileiro de Geografia e Estatística (IBGE/SUPREN), Rio de Janeiro, $427 \mathrm{p}$.

[43] Eskinazi-Leça, E., Maria da Glória, G., Koening, M.L., de Macêdo, S.J. and Costa, K.M.P. (1997) Variação Espacial e Temporal do Fitoplâncton na Plataforma Continental de Pernambuco-Brasil. Tropical Oceanography, 25, 1-16.

[44] Neves, S.P. and Mariano, G. (1999) Assessing the Tectonic Significance of a Large-Scale Transcurrent Shear Zone System: The Pernambuco Lineament, Northeastern Brazil. Journal of Structural Geology, 21, 1369-1383. https://doi.org/10.1016/S0191-8141(99)00097-8

[45] Kayano, M.T. and Andreoli, R.V. (2007) Relations of South American Summer Rainfall Interannual Variations with the Pacific Decadal Oscillation. International Journal of Climatology, 27, 531-540. https://doi.org/10.1002/joc.1417 
[46] Ramos, A.M., Santos, L.A.R. and Fortes, L.T.G. (Eds.) (2009) Normais Climatológicas do Brasil, 1961-1990. Instituto Nacional de Meteorologia-INMET, Ministério da Agricultura, Pecuária e Abastecimento-MAPA.

[47] Manso, V.A.V., Lima-Filho, M.F. and Oliveira, A.T. (1992) Macrozoneamento Costeiro do Litoral de Pernambuco-Folha Itamaracá-SB.25-Y-C-VII. Relatório Técnico. Recife. Laboratório de Geologia e Geofísica Marinha-LGGM. Departamento de Engenharia de Minas-DEMINAS-UFPE/CPRH.

[48] Muehe, D. (2006) Erosão e Progradação do Litoral Brasileiro. Ministério do Meio Ambiente, Brasília, v.1, 475 p.

[49] CPRM (2018) Brazilian Geological Survey. Technical Report of "Granulados Marinhos do Brasil" Project GRANMAR. http://www.cprm.gov.br/geo/pgb/inicio/Geol\%20Geof\%20Marinha.pdf

[50] Müller, G. (1967) Methods in Sedimentary Petrography (Part I). Hafner Publishing Co., New York, 283 p.

[51] Carver R.E. (1971) Procedures in Sedimentary Petrology. Wiley-Interscience, New York.

[52] Folk, R.L. (1954) The Distinction between Grain Size and Mineral Composition in Sedimentary-Rock Nomenclature. The Journal of Geology, 62, 344-359. https://doi.org/10.1086/626171

[53] Folk, R.L. and Ward, W.C. (1957) Brazos River Bar: a Study in the Significance of Grain Size Parameters. Journal of Sedimentary Research, 27, 3-26. https://doi.org/10.1306/74D70646-2B21-11D7-8648000102C1865D

[54] Vital, H., Silveira, I.M.D. and Amaro, V.E. (2005) Carta Sedimentólogica da Plataforma Continental Brasileira: Área Guamaré a Macau (NE Brasil), Utilizando Integração de Dados Geológicos e Sensoriamento Remoto. Revista Brasileira de Geofísica, 23, 233-241. https://doi.org/10.1590/S0102-261X2005000300003

[55] Vital, H., Stattegger, K., Amaro, V.E., Schwarzer, K., Frazão, E.P., Tabosa, W.F., \& Silveira, I.M. (2008) A Modern High-Energy Siliciclastic-Carbonate Platform: Continental Shelf adjacent to Northern Rio Grande do Norte State, Northeastern Brazil. In: Hampson, G., Steel, R., Burguess, P. and Dalrymple, R., Eds., Recent advances in Models of Siliciclastic Shallow-Marine Stratigraphy, SEPM Special Issue 90, 177-190. https://doi.org/10.2110/pec.08.90.0177

[56] Larsonneur, C. (1977) La Cartographie des Depots Meubles sur le Plateau Continental Français: Méthode Mise au Point et Utilisée en Manche. Journal de Recherché Océanographique, 2, 33-39.

[57] Hedges, J.I. and Stern, J.H. (1984) Carbon and Nitrogen Determinations of Carbonate-Containing Solids. Limnology and Oceanography, 29, 657-663. https://doi.org/10.4319/lo.1984.29.3.0657

[58] Fernandes, M.B., Sicre, M.A., Cardoso, J.N. and Macêdo, S.J. (1999) Sedimentary 4-desmethyl Sterols and $n$-Alkanols in an Eutrophic Urban Estuary, Capibaribe River, Brazil. Science of the Total Environment, 231, 1-16. https://doi.org/10.1016/S0048-9697(99)00077-7

[59] Regazzi, A.J. (2000) Análise multivariada, notas de aula INF 766, Departamento de Informática da Universidade Federal de Viçosa, v.2.

[60] Rashid, M.A. (1985) Physico-chemical Characteristics of Marine Humic Compounds. In: Rashid, M.A., Ed., Geochemistry of Marine Humic Compounds, Springer, New York, 66-107. https://doi.org/10.1007/978-1-4615-7098-1 3

[61] Furtado, V.V., Barcellos, R.L., Conti, L.A., Rodrigues, M. and Mahiques, M.M. (2008) 
Sedimentação. In: Pires-Vanin, A.M.S., Ed., Oceanografia de um ecossisitema subtropical-Plataforma de São Sebastião, EDUSP, São Paulo, 141-180.

[62] Oliveira, T.R.S., Santos, L.D., Silva, J.C.A., Eichler, P.P.B. and Barcellos, R.L. (2019) Correlação entre Características Sedimentológicas e Foraminíferos Bentônicos no Porto de Suape (PE-Brasil): Um Estudo Ambiental. Anuário do Instituto de Geociências (UFRJ. Impresso), 42, 159-168. https://doi.org/10.11137/2019 $2 \quad 159168$

[63] Lima-Filho, M.F., Barbosa, J.A. and de Souza, E.M. (2006) Eventos Tectônicos e Sedimentares nas Bacias de Pernambuco e da Paraíba: Implicações no Quebramento do Gondwana e Correlação com a Bacia do Rio Muni. Geociências, 25, 117-126.

[64] Romankevich, E.A. (1984) Geochemistry of Organic Matter in the Ocean. Springer-Verlag, New York, 334 p. https://doi.org/10.1007/978-3-642-49964-7

[65] Paropkari, A.L., Iyer, S.D., Chauhan, O.S. and Babu, C.P. (1991) Depositional Environments Inferred from Variations of Calcium Carbonate, Organic Carbon, and Sulfide Sulphur: A Core from Southeastern Arabian Sea. Geo-Marine Letters, 11, 96-102. https://doi.org/10.1007/BF02431036

[66] Santos, L.D. and Barcellos, R.L. (2017) Sedimentação Atual do Estuário do Rio Formoso-PE (Brasil). NEA-Edições, Saarbrucken, 113 p.

[67] Barcellos, R.L., Oliveira, L.E.E. and Montes, M.J.F. (2018) Spatial Sedimentary Distribution, Seasonality and the Characteristics of Organic Matter on Fernando de Noronha Insular Shelf. Brazilian Journal of Oceanography, 66, 131-156.

[68] Camargo, J M.R., Araújo, T.C.M., Ferreira, B.P. and Maida, M. (2015) Topographic Features Related to Recent Sea-Level History in a Sediment-Starved Tropical Shelf: Linking the Past, Present and Future. Regional Studies in Marine Science, 2, 203-211. https://doi.org/10.1016/j.rsma.2015.10.009

[69] Pardal, E.C., Xavier, D.A., Oliveira, I.M.V., Flores-Montes, M. J. and Barcellos, R.L. (2019) Variabilidade Sedimentológica e Geoquímica em um Sistema Estuarino Tropical sob Forte Influência Antrópica no Nordeste Brasileiro (Rio Capibaribe-PE). Pesquisas em Geociências, 46, E0852. https://doi.org/10.22456/1807-9806.97386

[70] Martins, S.E.M., Barcellos, R.L., Flores-Montes, M.J. and Franca, E.J. (2016) Depositional Evolution in a Estuarine Lagoonal System Under a Port Influence in Northeastern Brazil. Journal of Coastal Research, 75, 84-88.

https://doi.org/10.2112/SI75-017.1

[71] Redfield, A., Ketchum, B. and Richards, F., (1963) The Influence of Organisms on the Composition of Seawater. In: Hill, M.N., Ed., The Sea, Vol. 2, The Composition of Sea-Water Comparative and Descriptive Oceanography, Interscience Publishers, New York, 26-77.

[72] Faganeli, J., Pedzic, J., Ogorelec, B., Misic, M. and Najdek, M. (1994) The Origin of Sedimentary Organic Matter in the Adriatic. Continental Shelf Research, 14, 365-384. https://doi.org/10.1016/0278-4343(94)90024-8

[73] Dominguez, J.M.L., Bittencourt, A.C.S.P. and Leão, Z.M.A.N. (1990) Geologia do Quaternário Costeiro do Estado de Pernambuco. Revista Brasileira de Geociências, 20, 208-215. https://doi.org/10.25249/0375-7536.1990208215

[74] Summerhayes, C.P., Coutinho, P.N., França, A.M.C. and Ellis, J.P. (1975) Salvador to Fortaleza, North-Eastern Brazil. Contributions to Sedimentology, 4, 44-77.

[75] França, A.M.C. (1979) Geomorfologia da Margem Continental Leste Brasileira e da Bacia Oceânica Adjacente. In: CENPES/DINTEP, Geomorfologia da Margem Continental Brasileira e das Áreas Oceânicas Adjacentes PETROBRÁS, Rio de Janeiro, 89-127. 
[76] Weschenfelder, J., Corrêa, I.S.C., Toldo Jr., E.E. and Baitelli, R. (2008) Paleocanais como indicativo de eventos regressivos quaternários do nível do mar no sul do Brasil. Revista Brasileira de Geofísica, 26, 367-375. https://doi.org/10.1590/S0102-261X2008000300009

[77] Conti, L.A. and Furtado, V.V. (2009) Topographic Registers of Paleo-Valleys on the SouthEastern Brazilian continental Shelf. Brazilian Journal of Oceanography, 57, 113-121.

[78] Vital, H., Furtado, S.F.L. and Gomes, M.P. (2010) Response of the Apodi-Mossoró Estuary Incised Valley System (NE Brazil) to Sea-Level Fluctuations. Brazilian Journal of Oceanography, 58, 13-24.

[79] Barletta, M. and Costa, M. F. (2009) Living and Non-Living Resources Exploitation in a Tropical Semi-Arid Estuary. Journal of Coastal Research, 75, 371-375.

[80] Saito, Y., Nishimura, A. and Matsumoto, E. (1989) Transgressive Sand Sheet Covering the Shelf and Upper Slope of Sendai, Northeast Japan. Marine Geology, 89, 245-258. https://doi.org/10.1016/0025-3227(89)90078-9

[81] Bader, R.G. (1955) Carbon and Nitrogen Relations in Surface and Subsurface Marine Sediments. Geochimica et Cosmochimica Acta, 7, 205-211.

https://doi.org/10.1016/0016-7037(55)90032-6

[82] Cloern, J.E., Canuel, E.A. and Harris, D. (2002) Stable Carbon and Nitrogen Isotope Composition of Aquatic and Terrestrial Plants of the San Francisco Bay Estuarine System. Limnology and Oceanography, 47, 713-729.

https://doi.org/10.4319/lo.2002.47.3.0713 